\section{TEXAS}

VOLUME 50

\section{LAW}

MAY 1972
REVIEW

NUMBER 5

\title{
GREAT CASES MAKE BAD LAW: THE WAR POWERS ACT
}

\section{EUGENE V. ROSTOW*}

Great cases like hard cases make bad law. For great cases are called great, not by reason of their real importance in shaping the law of the future, but because of some accident of immediate overwhelming interest which appeals to the feelings and distorts the judgment. These immediate interests exercise a kind of hydraulic pressure which makes what previously was clear seem doubtful, and before which even well settled principles of law will bend.

HoLmes, J., dissenting in Northern

Securities Co. v. United States, 193

U.S. 197, 400-01 (1904).

The circumstances that endanger the safety of nations are infinite, and for this reason no constitutional shackles can wisely be imposed on the power to which the care of it is committed.

Alexander Hamilton, The FEDERALIST No. 23

The legislative department is everywhere extending the sphere of its activity, and drawing all power into its impetuous vortex ... it is against the enterprising ambition of this department that the people ought to indulge all their jealousy and exhaust all their precautions.

James Madison, The Federalist No. 48

\section{INTRODUGTION}

Responding to the bitterness and tragedy of Vietnam, a group of Senators led by Jacob K. Javits of New York proposes fundamentally to

- Sterling Professor of Law and Public Affairs at Yale University. This article is based on the author's Leon Green Address, delivered at the Fiftieth Anniversary Dinner of the TExAs LAW REvIEW, March 11, 1972. It is a pleasure to note my admiration for Dean Green, and my enthusiasm for his distinguished service to the law, and to our law schools. 
change the constitutional relationship between President and Congress in the field of foreign affairs. ${ }^{1}$ They assert that the underlying cause of the Vietnam tragedy is a modern and most unconstitutional excess of presidential power-a shift in the rightful balance of authority between the two branches caused by presidential "usurpations" at least since the time of McKinley, and especially those they claim Lyndon B. Johnson made with regard to Vietnam.

Ignoring their own repeated votes for Vietnam, these Senators say, "We live in an age of undeclared war, which has meant Presidential war. Prolonged engagement in undeclared, Presidential war has created a most dangerous imbalance in our Constitutional system of checks and balances."2 Although Senator John Sherman Cooper has rightly criticized their theory as a rewriting of history, without factual foundation, ${ }^{3}$ these men have offered a Bill which in their view would correct nearly two hundred years of error, strip the Presidency of many of its most essential powers, and restore what they fondly imagine was the constitutional model of 1789.

This contention, which is the major premise of the Senate Foreign Relations Committee Report on the Javits Bill, confuses two concepts, one of international law, the second of American constitutional law. "Undeclared" (or "limited" or "imperfect") war is a category of public international law, used to denote hostilities on a considerable scale conducted in time of "peace" rather than of "war," so far as international

The present version of the address draws on passages from PEACE IN THE BALANCE: The Future of AMERICAN Foreign PoLicy, to be published during 1972 by Simon \& Schuster, Inc., of New York.

1 Senate Comm. on Foreign Relations, War Powers, S. Rer. No. 92-606, 92d Cong., 2d Sess. (1972), to accompany S. 2956, 92d Cong., 2d Sess. (1972) [hereinafter cited as WAR PowERs]; War Powers Legislation, Hearings on S. 731, S.J. Res. 18, and S.J. Res. 59 Before the Senate Comm. on Foreign Relations, 92d Cong., Ist Sess. (1972) [hereinafter cited as 1971 Hearings]. See also Senate Comm. ON Forfign Retations, 91st Conc., 20 Sess., Documents Relating to the War Power of Congress, the Presment's Authortiy as ComMANDER-IN-CHIEF AND THE WAR IN INDOchINA (Comm. Print 1970) [hereinafter cited as Documents]; Congress, the President, and the War Powers, Hearings Before the Subcomm. on National Security Policy and Scientific Developments of the House Comm. on Foreign Affairs, 9lst Cong., 2d Sess. (1970) [hereinafter cited as 1970 Hearings].

2 WAR POWERs, supra note 1 , at 3.

$B$ In a statement of individual views, Senator Cooper remarks:

I do not concur in one underlying theme of the Committee's report-which was never discussed in Committee and never voted on-that the Executive las taken from the Congress its powers. The record, if studied, discloses that the Congress, particularly since World War II, has not only acceded to but has supported Executive resolutions requesting Congressional authority to use the armed forces of the United States, if necessary, in hostilities.

These are settled facts of history. We can change our course but we cannot Id. at 32 . revise and rewrite history. 
law is concerned. "Presidential" war, as the Committee uses the phrase, obviously refers to hostilities undertaken by the United States, and authorized by the President alone. The United States, like most other nations during the last two and a half centuries, has rarely chosen to invoke the international law of war by solemnly "declaring" that a state of war exists, signalling maximum hostility, and implying the invasion or even the destruction of an enemy state. But a considerable number of our many "limited" or "undeclared" wars, like Vietnam itself, have been authorized by Congress as well as the President through procedures which have been approved in usage and in Supreme Court opinions since the first years of the nation under the Constitution of 1789 . Such hostilities cannot therefore be described as "Presidential."

The Javits Bill rests on heady new perspectives the Senate Foreign Relations Committee has discovered in the necessary and proper clause. ${ }^{4}$ Its doctrine would permit a plenipotentiary Congress to dominate the Presidency (and the courts as well) more completely than the House of Commons governs England; that is, it would permit Congress to amend the Constitution without the inconvenience of consulting the people.

The battle cry of "constitutional usurpation" quickens the blood of every Congressman, and indeed of every American..$^{5}$ Accustomed as we are to treat nearly all questions of policy as questions of constitutional law, we find it easy to conclude that whatever we dislike intensely must also, and therefore, be unconstitutional as well. It is as natural for us to preach a return to the true orthodoxy of the Founding Fathers as it is for devout Moslems to make a pilgrimage to Mecca.

Holmes once remarked that great cases, like hard cases, make bad law. The Javits Bill confirms Holmes' quip more vividly than any proposal since that of the Bricker Amendment, which was in part a response to the Korean War. We should find safer outlets than the Javits Bill for the hydraulic pressure of our present discontents about Vietnam.

1 Members of Congress have themselves perhaps underestimated the authority vested in them by the "necessary and proper" clause of Article I, Section 8, of the Constitution. That clause entrusts the Congress to make all laws "necessary and proper for carrying into execution" not only its own powers but "all other powers vested by this Constitution in the Government of the United States, or in any department or office thereof." Strictly interpreted, the "necessary and proper" clause entrusts the Congress not only to "carry into execution" its own constitutional war power, but also, should it be thought necessary, to define and codify the powers of the government as a whole, including those of the President as its principal officer.

Id. at 16. See discussion pp. 896-97 infra.

5 Youngstown Sheet \& Tube Co. v. Sawyer, 343 U.S. 579, 594 (1952), (Frankfurter, J., concurring). 
We wisely refrained from curbing the powers of the Supreme Court even after the catastrophic error of Dred Scott. The same calm prudence should guide our course now, with respect to the Presidency.

The Javits Bill rests on a premise of constitutional law and constitutional history which is in error. Its passage would be a constitutional disaster, depriving the government of the powers it needs most to safeguard the nation in a dangerous and unstable world. Even if a President were to ignore such a statute, assuming that it passed over his veto, on the ground that it is unconstitutional, the passage of the Bill would create uncertainties, and envenom politics, in ways which would themselves be dangerous, both at home and abroad. It would tend to convert every crisis of foreign policy into a crisis of will, of pride, and of precedence between Congress and the President, making the policy process even more athletic than it is today.

The Javits Bill is a more serious attack on the Constitution and the security of the nation than one or another of the Bricker Amendments, which were nearly recommended by the Congress in the middle fifties. Those Amendments dealt only with the legal effect of treaties as internal law. They would have required affirmative action by Congress before treaties become operative as the supreme law of the land. ${ }^{6}$

The Javits Bill is more ambitious. It would allow the President, as the constitutional head of state, commander-in-chief, and representative of the nation in the conduct of foreign affairs, to use the armed forces of the United States in five and only five classes of cases: pursuant (1) to a declaration of war, or (2) to a specific statutory authorization of undeclared war passed after the passage of the Javits Bill itself, and specifically exempting a proposed use of force from its provisions, or like legislation in force at the time of the enactment of the Javits Bill, if it is sufficiently "specific"; absent such Congressional mandates, the

6 Association of the Bar of the City of New York, Report on the 1957 Bricker Amendment, 12 TaE RECORD 320 (1957); Bricker \& Webb, Treaty Law v. Domestic Constitutional Law, 29 NOTRE DAME LAw. 529 (1954); Hatch, Finch \& Ober, The Treaty Power and the Constitution: The Case for Amendment, 40 A.B.A.J. 207 (1954); Macchesney, The Fallacies in the Case for the Bricker Amendment, 29 Notre DAME LAw. 551 (1954); MacChesney, McDougal, Mathews, Oliver \& Ribble, The Treaty Power and the Constitution: The Case Against Amendment, 40 A.B.A.J. 203 (1954).

7 S. 2956, 92d Cong., 2d Sess. § 3 (1972):

In the absence of a declaration of war by the Congress, the Armed Forces of the United States may be introduced in hostihities, or in situations where imminent involvement in hostilities is clearly indicated by the circumstances, only ... (4) pursuant to specific statutory authorization, but authority to introduce the Armed Forces of the United States in hostilities or in any such situation shall not be inferred (A) from any provision of law hereafter enacted, including any provision contained in any appropriation Act, unless such provision specifically authorizes the introduction of snch Armed Forces in hostilities or in such situation and specifically exempts the introduction of such Armed Forces from compli- 
Bill would permit the use of the armed forces of the United States by the President only (3) to repel an armed attack on the United States, or (4) on the armed forces of the United States located outside of the United States; to forestall the direct and imminent threat of such an armed attack; to retaliate against armed attacks on the United States (not, however, against armed attacks on the armed forces of the United States located outside of the United States); or (5) to protect American citizens abroad being evacuated from a situation of direct and imminent threat to their lives. And in all hostilities except those authorized by a declaration of war-that is-those of "specific" advance statutory authorization of undeclared war; the evacuation of citizens in danger; and of armed attack on the United States or on its forces-the President could not use force for more than thirty days unless Congress ratified his course within that period or had exempted the particular use of force from the Javits Act in advance. The Bill would also require the President to report in writing to both Houses of Congress regarding the introduction of the armed forces "in hostilities, or in any situation where imminent involvement in hostilities is clearly indicated by the circumstances,"8 and provides that within thirty days Congress could overrule even a President's decision to use force in conformity with the Bill by an act or joint resolution.

The Javits Bill would annul the military provisions of all outstanding treaties, and probably of other legislative commitments dealing with the use of force as well, including the authority specified in the Middle Eastern Resolution and other Resolutions of similar import. ${ }^{9}$ We should

ance with the provisions of this Act, or (B) from any treaty hereafter ratified unless such treaty is implemented by legislation specifically authorizing the introduction of the Armed Forces of the United States in hostilities or in such situation and specifically exempting the introduction of such Armed Forces from compliance with the provisions of this Act. Specific statutory authorization is required for the assignment of members of the Armed Forces of the United States to command, coordinate, participate in the movement of, or accompany the regnlar or irregular military forces of any foreign country or government when such Armed Forces are engaged, or there exists an imminent threat that such forces will become engaged, in hostilities. No treaty in force at the time of the enactment of this Act shall be construed as specific statutory authorization for, or a specific exemption permitting, the introduction of the Armed Forces of the United States in hostilities or in any such situation, within the meaning of this clause (4); and no provision of law in force at the time of the enactment of this Act shall be so construed unless such provision specifically authorizes the introduction of such Armed Forces in hostilities or in any such situation.

How one Congress could constitutionally bind its successors in this way passes my understanding. The problem is hardly comparable to the provisions of $\S 12$ of the Administrative Procedure Act, providing guidelines to the courts in interpreting subsequent statutes as repeals by implication. 60 Stat. 244, (1946), 5 U.S.C. \& 559 (1970); Rusk v. Cort, 369 U.S. 367 (1962).

8 S. 2956, 92d Cong., 2d Sess. \& 4 (1972).

9 Middle East Resolution, Pub. L. No. 85-7, 71 Stat. 5 (1957), as amended, Pub. L. 
become the only nation in the world unable to make credible treaties or other security commitments. If the Javits Bill should become law, there would be a difficult and dangerous hiatus, maximizing uncertainty, until new treaties could be negotiated, and new legislation confirming them be considered and passed. With respect to the use of the armed forces by the President acting without prior authorization from Congress, the Bill would abolish at least half the categories in a pattern of practice which extends in an unbroken line of more than 150 instances to the Presidency of George Washington; equally, it would put the Presidency in the straitjacket of a rigid code, and prevent new categories of action from emerging, in response to the necessities of a tense and unstable world. Under the Javits Bill, no President could make a credible threat to use force as an instrument of deterrent diplomacy, even to head off explosive confrontations. And, on those occasions when the Bill would authorize the President to move quickly, the reporting requirements could well of themselves blow every secret diplomatic brush into a major crisis.

The Javits Bill is full of paradox. While its nominal motivation is to assure the nation that a pacific Congress will staunchly keep jingo Presidents from engaging in limited wars like that in Vietnam, the Bill would not have prevented the campaign in Vietnam if it had been enacted thirty years ago. Our participation in Vietnam was specifically authorized by President Eisenhower's SEATO Treaty, and by several

No. 87-195, 75 Stat. 424 (1961); Formosa Resolution, ch. 4, 69 Stat. 7 (1955); Berlin Resolution, H.R. Con. Res. 570, 87th Cong., 2d Sess., 118 CoNG. REc. 22637 (1962); Cuba Resolution, Pub. L. No. 87-739, 76 Stat. 697 (1962); The United Nations Participation Act of 1945, ch. 583, 59 Stat. 619 (1949), as amended, ch. 660, 63 Stat. 734 (1949), Pub. L. No. 86-707, 74 Stat. 797 (1960), Pub. L. No. 89-206, 79 Stat. 841 (1965).

The last clause of $\S 3(4)$ of the Javits Bill, quoted in note 7 supra, is ambiguous on this point. Nor is it clarified in the Senate Report on the Bill, WAR PowERs, supra note 1. The important question remains whether the language of outstanding statutes and Joint and Concurrent Resolutions should be regarded as "specific" enough to survive the passage of the Bill, in view of the first sentence of $\S 3(4)$, and the flat statement that "no treaty in force at the time of the enactment of this Act shall be construed as specific statutory authorization for, or a specific exemption permitting, the introduction" of the armed forces in hostilities.

The Middle East Resolution, for example, provides that the United States regards as vital to the national interest and world peace the preservation of the independence and integrity of the nations of the Middle East. To this end, if the President determines the necessity thereof, the United States is prepared to use armed forces to assist any such nation or group of such nations requesting assistance against armed aggression from any country controlled by international communism: Provided, That such employment shall be consonant with the treaty obligations of the United States and with the Constitution of the United States. Pub. L. No. 85-7, § 2, 71 Stat. 5 (1957).

In view of the policies of strict construction and Congressional control embodied in the Javits Bill, would this language be construed to authorize Presidential action to assist Jordan, for example, against an attack from (or by) Syria? 
other laws, including the Tonkin Gulf Resolution, which authorized the use of armed force by the President to carry out that Treaty.10 The procedures used to bring Congress and the Presidency together behind the campaign in Vietnam fully comply with the substantive standards of the Javits Bill. In the case of Korea, the Bill would have required President Truman to obtain a Congressional Resolution within 30 days supporting the action he took under the United Nations Charter, which has the status of a treaty in our legal system. That Resolution could surely have been obtained at the time, although the President and the Congressional leaders thought it unwise and unnecessary to do so. ${ }^{11}$

If the Javits Bill had been on the books, it would have prevented President Kennedy from resolving the Cuban Missile Crisis as he did, by the skillful and minimal deployment of our armed forces as an instrument of diplomatic deterrence and persuasion, in the interest of protecting vital national interests without precipitating nuclear war, or any other kind of war. In its Report, the Senate Foreign Relations Committee, relying on testimony by Professor Bickel, asserts that the Cuban Missile Crisis could have been treated under Section 3(1) of the Javits Bill as a case of forestalling "the direct and imminent threat" of armed attack on the United States. The United States government, however, has made no such claim, even under the "inherent" right of selfdefense provision of Article 51 of the United Nations Charter, far broader than the Javits Bill in its reach. Indeed, the notion that the Soviet Union in 1962 was about to launch nuclear missiles against the United States from Cuba, knowing that it would have received a nuclear attack in response, is incredible. The Cuban Missile Crisis, real as it was, must be seen as part of the push and pull of Soviet-American diplomacy, in the context of the Berlin and Laos crises of the period, President Kennedy's Vienna meeting with Khrushchev, the Bay of Pigs fiasco, and other factors. ${ }^{12}$

10 See discussion pp. 872-885 infra.

11 See discussion pp. $867-870$ infra.

12 R. KENNEDY, ThIRTEEN Days 31-33, 111-19, Afterword by R. Neustadt \& G. Allison, 138-39 (1969); KARUSHChEv REMEMBERs ch. 20 (S. Talbott ed. 1971); WAR PoWERs, supra note 1, at 4; Chayes, Law and the Quarantine of Cuba, 41 For. AFr. 550 (1963) (expressly refusing to rest the American legal case on "self-defense," even in the ample perspective of Article 51). The most penetrating analysis of the crisis is A. WOHLSTETTER \& $R$. WOHLSETTER, Controlling THE RISKS IN CUBA (1965). See also INTERNATIONAL LAW AND POLITICAL Crists (L. Sheinman \& D. Wilkinson eds. 1968); MacChesney, Some Comments on the "Quarantine" of Cuba, 57 AM. J. INT"L L. 592 (1963); McDougal, The Soviet-Cuban Quarantine and Self-Defense, 57 Arr. J. INT'L L. 597 (1963).

In the Cuban case, Congress had passed a Resolution less than a month before the Missile Crisis of 1962, authorizing the President to use force if necessary to prevent "the 
Under the Javits Bill, President Johnson could not have employed the implicit threat of force to keep the Soviets out of the Six Day War in 1967, ${ }^{13}$ and President Nixon could not have used the same method to avert a general war in the Middle East in September, 1970, or to confine and contain the India-Pakistan War of 1972. Nor could earlier Presidents have used or threatened to use the nation's armed forces to persuade France to leave Mexico in 1865-66, to avoid war with Spain or Britain over Florida, or to send Commodore Perry on his fateful voyage to Japan.

As Senator Javits has said with admirable candor, the purpose of his Bill is to reduce the elective Presidency, which the Founding Fathers were at pains to establish as a third autonomous and coequal branch of the government, to the humble posture of George Washington during the Revolution, when he functioned as commander-in-chief, appointed by the Continental Congress, and its creature, or the creature of its committees, in every respect. ${ }^{14}$ I should have supposed that if anything is clear about the intent of the Founding Fathers, it is that one of the major goals of the Philadelphia Convention was to remedy what was

Marxist-Leninist regime in Cuba" from extending its activities by force or the threat of force to any part of the hemisphere. The Resolution also announced our determination to prevent in Cuba the creation or use of an externally supported military capability endangering the security of the United States. That clause of the Resolution, unlike clause (a), did not mention the use of arms. See Cuban Resolution, note 9 supra. Mr. Chayes believes, however, that the Resolution was "one of the bases" of the President's authority to do what he did. 1970 Hearings, supra note 1, at 138. It would seem a better reading of the Cuban Resolution, in light of the restrictive policy of the Javits Bill, to interpret it as contemplating what President Johnson did in the Dominican Republic, but not what President Kennedy did before and during the Missile Crisis.

13 L. Johnson, The VANTAge PoINT 301-03 (1971).

14 "The Case for War Powers Legislation," Address to the American Bar Association Standing Comm. on World Order under Law, Hearing on War Powers of the President and Congress, Feb. 5, 1972, at 4-5.

Because this important speech is not yet readily available in libraries, it may be convenient to quote its extraordinary conclusion in full:

Clearly, the drafters of the Constitution had in mind the experience of the Continental Congress with George Washington when they designated the President as "Commander-in-Chief" in Article II Section 2. Thus, the "Iegislative history" of the Constitutional concept of a Commander-in-Chief was the relationship of George Washington as colonial Commander-in-Chief to the Continental Congress. That relationship is clearly defined in the Commission as Commander-inChief which was given to Washington on June 19, 1775 .

I would like to quote the final clause of this Commander-in-Chief's Commission, because it establishes the relationship of the Congress to the Commander-inChief in unmistakable terms:

"AND you are to regulate your conduct in every respect by the rules and discipline of war (as herewith given your) and punctually to observe and follow such orders and directions from time to time as you shall receive from this or a future Congress of the said United Colonies or a committee of Congress for that purpose appointed."

This historical background clarifies, and gives added meaning to, those phrases in the Constitution concerning the war powers which are the subject of such contemporary controversy. 
perceived as a critical weakness of the Articles of Confederation, namely, the absence of a strong and independent executive. The British monarch was much more in their minds as a point of departure than the revolutionary commander.

A wistful and nostalgic chord runs through the testimony and the speeches which favor the Javits Bill. The Founding Fathers, the distinguished and appealing proponents of the Bill say, wanted to make it hard to go to war, and easy to make peace. They wanted America to remain aloof from the quarrels of a naughty world, to eschew the pride and arrogance of power, and to use force only when openly attacked. Let us return to the wisdom of the patriarchs and prophets, these leaders tell us, and require Congress itself-or perhaps even the people through a referendum - to authorize every use of the sword. Thus they would wrap a foreign policy of nearly pacifist isolationism in the priestly mantle of constitutional command.15

The Bill's supporters dismiss the fact that the men who made the Constitution had quite another view of its imperatives when they became Presidents, Senators, Congressmen, and Secretaries of State. The words and conduct of the Founding Fathers in office hardly support the simplified and unworldly models we are asked to accept as embodiments of the only True Faith. Nor did the policies the Founding Fathers adopted when they became officials always shine with the innocence of Professor Commager's spirit. Above all, the essence of the Constitution was to build a framework which could last for ages. To suppose that the Constitution binds the nation forever to a particular foreign policy, or even a particular theory for foreign policy, is a fantasy, entirely alien to the chilly realism of No. 23 of The Federalist, and of McCulloch $v$. Maryland. The makers of the Constitution built in anticipation of changes in world politics that could not be anticipated in 1787. They wished to endow their successors with the full freedom of democratic responsibility to choose the foreign policy they found best suited to the politics and military technology of the period in which they lived. If the Constitution does not enact the Social Statics of Herbert Spencer, it surely does not enact the foreign policy of William E. Borah or J. William Fulbright. Constitutionally, the United States is as free to follow McKinley's example in making its foreign policy as that of Cleveland.

The constitution of the United States is a process-a process of

151971 Hearings, supra note 1, at 8-74 (testimony of Professor H. S. Commager), 7585 (testimony of Professor R. B. Morris). 
tension, conducted in a matrix of custom, and guided by certain standards, habits, and rules. Justice Brandeis once said that

$[t]$ he doctrine of the separation of powers was adopted by the Convention of 1787, not to promote efficiency but to preclude the exercise of arbitrary power. The purpose was, not to avoid friction, but, by means of the inevitable friction incident to the distribution of the governmental powers among three departments, to save the people from autocracy. ${ }^{16}$

The same theme runs through the Federalist papers.

In the contest for preeminence between President and Congress which constitutes one phase of Justice Brandeis' vision, the Javits Bill is nearly alone. Congress has made no bid for supremacy so bold, and so foreign to the American Constitution, since the impeachment of Andrew Johnson. The Bill would not restore the constitutional balance of 1787; it would profoundly alter that balance with regard to the conduct of foreign relations, as it has evolved in nearly two hundred years of testing experience.

I reach this conclusion not as an advocate of increased presidential power, but as a defender of the constitutional pattern of enforced cooperation between President and Congress we have inherited, for all the friction it inevitably generates. I disagree with the arguments for enlarged presidential power put forth in recent years by McGeorge Bundy, James McGregor Burns, and Senator Fulbright. ${ }^{17}$ No President, and no Congress, can develop or carry out a foreign policy unless in fact they work together. Of course Congress should participate, and participate as early as possible, in decisions involving major and sustained hostilities, through processes of continuous consultation, and, where desirable and feasible, through formal legislative actions approving declared or undeclared war. That is now the pattern of our politics, and of our constitutional usage. The respective powers of each branch are indispensable if the making and execution of foreign policy are to remain under effective democratic control. Our practice is strenuous, and hardly conducive to a quiet, easy life, either for Presidents or for members of Congress. A quiet life for public officials is not, however, the most important goal of our constitutional arrangements and practices. There is no safe way to codify those arrangements and practices,

16 Myers v. United States, 272 U.S. 52, 293 (1926) (Brandeis, J., dissenting).

17 M. Bundy, The Strength of Government (1968); J. Burns, PrestDential GovernMENT (1965); R. Neustadt, Presidential PowER; ThE Politics of LEAdERshIP (1968); 1970 Hearings, supra note 1, at 81 (testimony of Dr. Burns); Fulbright, American Foreign Policy in the 20th Century Under an 18th-Century Constitution, 47 CORNELL L.Q. 1 (1961). 
especially with regard to the use of nuclear weapons, in ways which could meet all the contingencies likely to arise. It is striking that Senator Fulbright was alone on the Senate Foreign Relations Committee in urging a congressional vote before the President could legally use the nuclear weapon. ${ }^{18}$

Gouverneur Morris remarked that "no constitution is the same on paper and in life."19 Justice Frankfurter carried the thought further, writing about the relation between President and Congress in regard to the war power:

$[T]$ he content of the three authorities of government is not to be derived from an abstract analysis. The areas are partly interacting, not wholly disjointed. The Constitution is a framework for government. Therefore the way the framework has consistently operated fairly establishes that it has operated according to its true nature. Deeply embedded traditional ways of conducting government cannot supplant the Constitution or legislation, but they give meaning to the words of a text or supply them. It is an inadmissibly narrow conception of American constitutional law to confine it to the words of the Constitution and to disregard the gloss which life has written upon them. In short, a systematic, unbroken, executive practice, long pursued to the knowledge of the Congress and never before questioned, engaged in by Presidents who have also sworn to uphold the Constitution, making as it were such exercise of power part of the structure of our government, may be treated as a gloss on executive Power vested in the President by $\S 1$ of Art. II. ${ }^{20}$

The Javits Bill repudiates that history root and branch, and seeks to substitute parliamentary government for the tripartite constitution we have so painfully forged.

\section{The Background of Constitutional Usage}

The most serious illusion of legal positivism is the notion that "the original intention" of those who drafted and voted for a law is thereafter knowable, save as a guideline of broad purpose or principle. The debates of judges and scholars about the legitimacy of Marbury $v$.

18 WAR Powers, supra note 1 , at 26. Even Justice Goldberg, who vigorously urges a return to the "very plain language" of the Constitution, exempts the nuclear problem from his recommendations, 1971 Hearings, supra note 1, at 770-71.

19 I S. MORISON, OXFORD HISTORY OF THE UNITED STATES 103 (1st ed. 1927).

20 Youngstown Sheet \& Tube Co. v. Sawyer, 343 U.S. 579, 610-11 (1952) (Frankfurter, J, concurring). 
Madison, the scope of the commerce power, or the true import of the Fourteenth Amendment are evidence enough of the limited value of such inquests as a guide to later decisions. It is psychologically impossible for a man of the twentieth century, however learned and sensitive, to perceive the world as the men of $1787 \mathrm{did}$. There is no way for him to reproduce the structure and climate of their universe -to understand as they did the relation of the several parts to each other and the weight which various fears, concerns and ambitions had in their minds. ${ }^{21}$ The most important words John Marshall ever wrote were that we should never forget it is a constitution we are expounding - a constitution intended to endure for ages to come, and capable of adaptation to the various crises of human affairs-but a constitution nonetheless, assuring continuity as well as flexibility, boundaries of power, coupled with a wide freedom of democratic choice. ${ }^{22}$

How did the Founding Fathers intend to allocate the power to use the armed forces between the President and the Congress? I do not start here because I believe that we can conjure up from their few spare words on the subject a sacred norm of Arcadian purity to which at all costs we must "return," a tight model, capable, like a magical computer or coin machine, of providing clear solutions for every contingency likely to arise. The astute men who drafted the Constitution and started it on its way had a much deeper and more realistic sense of the relationship between law and life than that. Nonetheless, it is right as well as customary to start with the document, viewed against the background of their words and their experience, because the animating principles of their project-democratic responsibility, the theory of checks and balances in the exercise of shared powers, and civilian control of the military-have retained their vitality, and must continue to do so if we hope to survive as a free and democratic society.

In the perspective of political theory, the Presidency is one of the two great inventions of the Constitution, the other being judicial review. The weakness of the Executive under the Articles of Confederation was one of the major reasons for convening the Constitutional Convention of

21 In 1857, W. H. Trescot, in his Diplomatic History of the Administration of WASHINGTON AND ADAMS, 1789-1801, at 7-8, remarked that

[i]t would be almost as easy for a man in the vigorous and varied activity of his matured life to realize faithfully to himself the uncertainty and weakness of his infancy, as for a citizen of the United States at the present day to reproduce the condition of his country at the date of that treaty which secured its independence the weakness of its institutions, its economic life, and its internal and external situation.

see also id. at 97.

22 E. Rostow, The Sovereign Prerogative: The Supreme Court and the Quest for LAW 121-24 (1962). 
1787. Problems of security and of diplomacy were among the dominant preoccupations of the men who met at Philadelphia, and first among their arguments for Union. The nation was surrounded by British, French and Spanish territories, to say nothing of hostile Indian tribes. The Founding Fathers were mortally afraid the United States might be dismembered as a pawn in the Great Game of European power politics. Their Revolution had succeeded because they had the help of France. They knew that France had not assisted the American revolutionaries because the Bourbon King was a secret republican at heart, or a believer in the right of revolution. They feared a turn of the wheel of European politics which might undo all that had been achieved, despite their military alliance with France. Hence their concern with the Presidency and with the establishment of clearly national authority over defense and foreign relations in the new constitution. Of the 85 Federalist papers, 26 are devoted to one or another aspect of the problem. ${ }^{23}$

23 The basic idea which governed the drafting of the provisions of the Constitution dealing with the safety of the nation was classically stated by Hamilton in No. 23 of THE FEDERALIST:

The principal purposes to be answered by union are these-the common defence of the members; the preservation of the public peace, as well against internal convulsions as external attacks; the regulation of commerce with other nations and between the States; the superintendence of our intercourse, political and commercial, with foreigu countries.

The authorities essential to the common defence are these: to raise armies; to build and equip fleets; to prescribe rules for the government of both; to direct their operations; to provide for their support. These powers ought to exist without limitation, beeause it is impossible to foresee or define the extent and variety of national exigencies, or the correspondent extent and variety of the means which may be necessary to satisfy them. The circumstances that endanger the safety of nations are infinite, and for this reason no constitutional shackles can wisely be imposed on the power to which the care of it is committed. This power ought to be co-extensive with all the possible combinations of such circumstances; and ought to be under the direction of the same councils which are appointed to preside over the common defence.

This is one of those truths which, to a correct and unprejudiced mind, carries its own evidence along with it; and may be obscured, but cannot be made plainer by argument or reasoning. It rests upon axioms as simple as they are universal; the means ought to be proportioned to the end; the persons, from whose agency the attainment of any end is expected, ought to possess the means by which it is to be attained.

Whether there ought to be a federal government intrusted with the care of the common defence, is a question in the first instance, open for discussion; but the moment it is decided in the affirmative, it will follow, that that government ought to be clothed with all the powers requisite to complete execution of its trust. And unless it can be shown that the circumstances which may affect the pubhic safety are reducible within certain determinate limits; unless the contrary of this position can be fairly and rationally disputed, it must be admitted, as a necessary consequence, that there can be no limitation of that authority which is to provide for the defence and protection of the community, in any matter essential to its efficacy-that is, in any matter essential to the formation, direction, or support of the NATIONAL Forces.

The FeDERALIST 142-49 (Modern Library ed. I937). Hamilton's views on the President's independent role in assuring the security of the nation were developed later in a number of papers. See, e.g., those collected by Professor R. B. Morris in ALEXANDER HAMmTon ANB 
The Presidency which emerged from the deliberations at Philadelphia as the repository of "the executive power" of the United States was a remarkable office. Its essence was that the incumbents be endowed with ample authority to discharge the executive task, both at home and abroad, but not enough to become tyrants or kings. As Clinton Rossiter concludes:

Considering the spirit of the age, which was still proudly and loudly Whiggish, the proposed Presidency was an office of unusual vigor and independence. As Hamilton was soon to point out in The Federalist, it joined energy, unity, duration, competent powers, and "an adequate provision for its support" with "a due dependence on the people" and "a due responsibility." The President had a source of election legally separated if not totally divorced from the legislature, a fixed term and untrammeled reeligibility, a fixed compensation (which could be "neither increased nor dimmished" while he was in office), immunity from collective advice he had not sought (whether tendered by the Court, the heads of executive departments, or a council of revision), and broad constitutional powers of his own. It would be his first task to run the new government: to be its administrative chief, to appoint and supervise the heads of departments and their principal aides, and to "take care" that the laws were "faithfully executed." $\mathrm{He}$ was to lead the government in its foreign relations, peaceful and hostile, and he was, it would appear, to be ceremonial head of state, a "republican monarch" with the prerogative of mercy. Despite the allegiance of the Convention to the principle of the separation of powers, it had by no means cut him off from the two houses of Congress. To them he could tender information and advice; over their labors he held a qualified but effective veto; at his request they were bound to convene "on extraordinary occasions." He was, in short, to be a strong, dignified, largely nonpolitical chief of state and government. ${ }^{24}$

The Founding of the NATION 209, 526-27 (1957); IV Works of AlExANDER Hamilton 227489 , esp. $432-44$ (2d ed. H. Lodge 1903).

24 C. Rossiter, 1787: THE Grand Convention 221-22 (1966).

Rossiter adds that the framers had in mind not an abstraction as President, but George Washington.

Washington was not a candidate for this or any other office on earth, but when Dr. Franklin predicted on June 4 that "the first man put at the helm will be a good one," . . . every delegate knew perfectly well who that first good man would be. We cannot measure even crudely the influence of the commanding presence of the most famous and trusted of Americans, yet we may be sure that it was sizable, that it pointed (as we know from Washington's recorded votes) toward unity, strength, and independence in the executive, and that the doubts of some old fashioned Whigs were soothed, if never entirely laid to rest, by the expectation that he would be chosen as first occupant of the proposed Presidency, and chosen and chosen again until claimed by the grave. The powers of the President "are full great," Pierce Butler wrote the following year to a relative in England, 
In the field of foreign affairs, Congress too was given far-ranging responsibility. While foreign affairs are not mentioned as such in the Constitution, it is apparent from The Federalist (for example, Nos. 64 and 69) that the conduct of diplomatic relations is an exclusively executive function, with the Senate sharing in the process of making treaties, and Congress as a whole entrusted with the legislative dimensions of the problem of making foreign policy. Among the legislative powers bearing on the making and conduct of foreign policy, Article I Section 8 mentions the power to appropriate moneys in providing for the common defense and general welfare; to define and punish piracies and felonies committed on the high seas and offenses against the Law of Nations; to declare war, grant letters of Marque and Reprisal, and make rules concerning captures on land and water; to raise and support armies, subject to the important proviso that no appropriation of money to that use shall be for a longer term than two years; to provide and maintain a Navy; to make rules for the government and regnlation of the land and naval forces; to provide for calling forth the militia to execute the laws of the union, suppress insurrections and repel invasions; and to provide for organizing, arming and disciplining the militia, subject to a reservation of authority in the states.

What emerges from the text, and from the discussions available in The Federalist, in Farrand, in Madison's notes, and in other contemporaneous sources, is a pattern of shared constitutional authority in this vital area, evoking the memory of tyrannies ancient and modern much in the minds of the Founding Fathers. It is not an hermetic separation of powers, but a scheme of divided power-what Hamilton called an intermixture of powers, the only effective way to prevent a monopoly of power in any one branch of government.

Of this problem, Madison said:

One of the principal objections inculcated by the more respectable adversaries to the Constitution, is its supposed violation of the political maxim, that the legislative, executive, and judiciary departments ought to be separate and distinct.

The accumulation of all powers, legislative, executive, and judiciary, in the same hands, whether of one, a few, or many, and whether hereditary, self-appointed, or elective, may justly be

and greater than I was disposed to make them. Nor, entre nous, do I believe they would have been so great had not many of the members cast their eyes towards General Washington as President; and shaped their Id. ideas of powers to be given a President, by their opinions of his virtue. 
pronounced the very definition of tyranny. ... [T] cannot be supported, and the ... maxim on which it relies has been totally misconceived and misapplied. ${ }^{25}$

25 THE FEDERALIST No. 47, at 312-13 (Modern Library ed. 1937). Referring to Montesquieu's famous analysis of the British constitution, and of British experience, Madison continued:

From these facts, by which Montesquieu was guided, it may clearly be inferred that, in saying "There can be no liberty where the legislative and executive powers are united in the same person, or body of magistrates," or, "if the power of judging be not separated from the legislative and executive powers," lie did not mean that these departments ought to have no partial agency in, or no control over, the acts of each other. His meaning, as his own words import, and still more conclusively as illustrated by the example in his eye, can amount to no more than this, that where the whole power of one department is exercised by the same hands which possess the whole power of another department, the fundamental principles of a free constitution are subverted. . . This, however is not among the vices of that constitution. The magistrate in whom the whole executive power resides cannot of himself make a law, though he can put a negative on every law; nor administer justice in person, though he has the appointment of those who do administer it. The judges can exercise no executive prerogative, though they are shoots from the executive stock; nor any legislative function, though they may be advised with by the legislative councils. The entire legislature can perform no judiciary act, though by the joint act of two of its branches the judges may be removed from their offices, and though one of its branches is possessed of the judicial power in the last resort. The entire legislature, again, can exercise no executive prerogative, though one of its branches constitutes the supreme executive magistracy, and another, on the impeachment of a third, can try and condemn all the subordinate officers in the executive department.

Id. at 314-15. In another of the Federalist Papers, Madison added:

[U]niess these departments be so far connected and blended as to give to each a constitutional control over the others, the degree of separation which the maxim requires, as essential to a free government, can never in practice be dnly maintained.

It is agreed on all sides, that the powers properly belonging to one of the departments ought not to be directly and completely administered by either of the other departments. It is equally evident, that none of them ought to possess, directly or indirectly, an overruling influence over the others, in the administration of their respective powers. It will not be demed, that power is of an encroaching nature, and that it ought to be effectually restrained from passing the limits assigned to it. After discriminating, therefore, in theory, the several classes of power, as they may in their nature be legislative, executive, or judiciary, the next and most difficult task is to provide some practical security for each, against the invasion of the others. What this security ought to be, is the great problem to be solved.

Will it be sufficient to mark, with precision, the boundaries of these departments, in the constitution of the government, and to trust to these parchment barriers against the encroaching spirit of power? This is the security which appears to have been principally relied on by the compilers of most of the American constitutions. But experience assures us, that the efficacy of the provision has been greatly overrated; and that some more adequate defence is indispensably necessary for the more feeble, agaiust the more powerful, members of the government. The legislative department is everywhere extending the sphere of its activity, and drawing all power into its impetuous vortex.

The founders of our republics have so much merit for the wisdom which they have displayed, that no task can be less pleasing than that of pointing out the errors into which they have fallen. A respect for truth, however, obliges us to remark, that they seem never for a moment to have turned their eyes from the danger to liberty from the overgrown and all-grasping prerogative of an hereditary magistrate; supported and fortified by an hereditary branch of the legislative authority. They seem never to have recollected the danger from legislative usurpations, which, by assembling all power in the same hands, must lead to the same tyranny as is threatened by executive usurpations. 
In what is probably his finest opinion, Justice Jackson commented on the exercise of their war powers by President and Congress in these terms:

Just what our forefathers did envision, or would have envisioned had they foreseen modern conditions, must be divined from materials almost as enigmatic as the dreams Joseph was called upon to interpret for Pharaoh. A century and a half of partisan debate and scholarly speculation yields no net result but only supplies more or less apt quotations from respected sources on each side of any question. They largely cancel each other. And court decisions are indecisive because of the judicial practice of dealing with the largest questions in the most narrow way.

The actual art of governing under our Constitution does not and cannot conform to judicial definitions of the power of any of its branches based on isolated clauses or even single Articles torn from context. While the Constitution diffuses power the better to secure liberty, it also contemplates that practice will integrate the dispersed powers into a workable government. It enjoins upon its branches separateness but interdependence, autonomy but reciprocity. ${ }^{26}$

The early years of the nation under the new constitution were a period of acute turbulence which tested the parchment rules of the document in the crucible of intense and sustained experience. The respective authority of Congress and the President with regard to the use

... [1] a representative republic, where the executive magistracy is carefully limited, both in the extent and the duration of its power; and where the legislative power is exercised by an assembly, which is inspired, by a supposed influence over the people, with an intrepid confidence in its own strength; which is sufficiently numerous to feel all the passions which actuate a multitude, yet not so numerous as to be incapable of pursuing the objects of its passions, by means which reason prescribes; it is against the enterprising ambition of this department that the people ought to indulge all their jealousy and exhaust all their precautions.

The legislative department derives a superiority in our governments from other circumstances. Its constitutional powers being at once more extensive, and less susceptible of precise limits, it can, with the greater facility, mask, under complicated and indirect measures, the encroachments which it makes on the coördinate departments. It is not unfrequently a question of real nicety in legislative bodies, whether the operation of a particular measure will, or will not, extend beyond the legislative sphere. On the other side, the executive power being restrained within a narrower compass, and being more simple in its nature, and the judiciary being described by landmarks still less uncertain, projects of usurpation by either of these departments would immediately betray and defeat themselves. Nor is this all: the legislative department alone has access to the pockets of the people, and has in some constitutions full discretion, and in all a prevailing influence, over the pecuniary rewards of those who fill the other departments, a dependence, is thus created in the latter, which gives still greater facility to encroachments of the former.

THE FEDERALIST No. 48, at 321-23 (Modern Library ed. 1937).

28 Youngstown Sheet \& Tube Co. v. Sawyer, 343 U.S. 579, 634-35 (1952) (Jackson, J., concurring). 
of the armed forces was a matter of active controversy. Several issues of principle were settled not only by the pattern of practice, but by decisions of the Supreme Court as well. The system of ideas that emerged from this period has special weight, since it was produced by the generation of men who had drafted and enacted the Constitution, and launched it on its course. The rules they established have dominated constitutional usage and doctrine ever since.

Among these rules, several are of particular importance to the theory of the Javits Bill. As Hamilton had anticipated, "the actual conduct of foreign negotiations, the preparatory plans of finance, the application and disbursements of the public moneys in conformity to the general appropriations of the legislature, the arrangement of the army and navy, the direction of the operations of war,-these, and other matters of a like nature" were accepted as normal prerogatives of the Presidency. ${ }^{27}$ At the other end of the spectrum, it was equally clear that only the Congress can "declare war," appropriate funds, and prescribe rules for governing the armed forces and for calling the militia into national service.

With regard to the actual employment of the armed forces, it is apparent that the term "declare war" in the Constitution referred to the classifications of the law of nations, which makes a sharp distinction between the law of war and the law of peace. ${ }^{28}$ The law of nations was

27 THE FEDERALIST No. 72, at 468.69 (Modern Library ed. 1937).

28 See, e.g., J. BRIERLY, THE LAW OF NATTONS (6th ed. H. Waldock 1963); C. HYDE, International LAW (2d rev. ed. 1945); M. MaDovgal \& F. FELICIANo, LAW AND Minimum Wordd Publyc ORder, 5-11, 138-43 (1961); L. OppenheIM, InTERnational LAW (8th ed. H. Lauterpacht 1955).

With regard to the construction of the phrase "declare war" in the Constitution, see L. Kotzsch, THE CONCEPT OF WAR IN CONTEMTORARY HISTORY AND INTERNATIONAL LAW 62 (1956); 1971 Hearings, supra note 1, at $462-64$ (testimony of J. N. Moore); Potter, The Power of the President of the United States to Utilize its Armed Forces Abroad, 48 AM. J. INT'L LAW 458 (1954). See also Miller v. The Ship Resolution, 2 U.S. (2 Dall.) 19, $21-23$ (1781).

Professor Wormuth recognizes that the language of Article $I \$ 8$ of the Constitution is addressed to the categories of the law of nations, but claims that under Article I Congress has the complete and exclusive right to initiate all forms of hostility recognized under international law, including, e.g., reprisals. The Vietnam War: The President versus the Constitution, Occasional Paper No. 1, Center for the Study of Democratic Institutions (1968), reprinted in 2 THE VIETNAMM WAR AND INTERNATroNAL LAW 711, 717-18 (R. Falk ed. 1969) [hereinafter cited as FALK]. This is surely going too far. Professor Wormuth, accepting the Hamiltonian view, acknowledges that the "Constitution recognizes that the power to initiate wars is lodged in two places: in Congress, and in a foreign enemy .... When a foreign country attacks the United States, war exists and the President as Commander-inChief may and must make-that is, wage-the war." Thus he concedes most of the case he opposes, for most Presidential uses of the armed forces rest on the President's judgment that he is resisting, forestalling, or retaliating against the hostile act of another state, illegal under international law, and directed against the security of the United States. See, e.g., The Prize Cases, 67 U.S. (2 Black) 635, 668, 671 (1863); Durand v. Hollins, 8 F. Cas. III, 112 (No. 4186) (C.C.S.D.N.Y. 1860); Note, 81 HARv. L. REv. 1771 (1968). 
an intimate familiar to the men of the revolutionary generation in America. So far as international law is concerned, nations were then, and are now, free to use force in time of peace by way of self-help against acts or policies of other nations which they deem contrary to international law, and which have remained unredressed after a demand for amends. Different words are used to describe various categories of selfhelp: retorsion; reprisal; pacific embargoes or blockades; limited intervention to protect nationals; humanitarian intervention to restore order in situations of massacre, natural disaster, or extreme civil disturbance; and others. They are all subsumed under the inherent and sovereign right of self-defense, which has been reenacted in Article 51 of the Charter of the United Nations. ${ }^{29}$ In the period before the United Nations, international law also accepted as legal other uses of force which now would be regarded as violating Article 2(4) of the Charter.

It is tempting, but would be incorrect, to suggest, as Hamilton did, that the constitutional allocation of power between President and Congress with respect to the use of the armed forces corresponds to the categories of international law, with the President authorized to use the armed forces as head of state and commander-in-chief in those situations in which international law would acknowledge the use of armed force as permissible self-help in time of peace, while only Congress could move the nation into the juridical world of a state of war, within the meaning of international law. The constitutional pattern is, and should be, more complex than any such formula.

In the formative years of the Republic, Presidents and Congress alike found that the exigencies of diplomacy in a world at war required many uses and threats to use military power which defied simplified classification. When in office, Jefferson, Madison, and Hamilton all discovered that they could not quite live according to the brave rules they had pronounced as theorists of the Constitution. Then, and since, the invocation of force as a tool of national policy ranged from the purely Presidential to the full declaration of war, the latter as rare in the eighteenth century and the early days of the nation as it has been in this century.

In Washington's first administration, Congress passed broad legislation under its power to provide for calling forth the militia to execute the laws of the union, suppress insurrections and repel invasions. These

29 D. BOWETT, SELF-DEFENSE IN INTERNATIONAL LAW (1958); F. KALSHOVEN, BELLIGERENT Reprisals (1971); M. MaDougal \& F. FeIJCIANo, supra note 28, ch. 3; A. Ross, The UnITED Nations: PEAce and Progress ch. 4 (1966); Bowett, Reprisals Involving Recourse to Armed Force, 66 AM. J. INT'L LAW I (1972) (collecting literature). 
early statutes and their application have been little altered by the passage of time, save in their steady enlargement of the President's prerogative. As standing delegations of emergency power, they bespeak the ultimate right of self-preservation which every nation possesses because it is a nation. Jefferson, Fillmore, and Pierce employed the power broadly. Lincoln relied on it during his first anxious months of resisting the Rebellion..$^{30}$ Hayes and Cleveland used force in situations of domestic turbulence almost without reference to the militia statutes, ${ }^{31}$ exercising inherent Presidential power unaided by legislation, and the Supreme Court upheld what Gleveland did in ringing terms. ${ }^{32}$ Truman, Kennedy, and Eisenhower invoked these and cognate statutes during various crises at home and abroad..$^{33}$

In view of current controversies about the constitutionality of congressional "delegations" to the President of the power to use the armed forces, the text of the first militia statute, that of 1789 , is significant:

That for the purpose of protecting the inhabitants of the frontiers of the United States from the hostile incursions of Indians, the President is hereby authorized to call into service from time to time, such part of the militia of the states respectively, as he may judge necessary for the purpose aforesaid. ${ }^{34}$

It was essential for the President to be able to use the militia, since the small Regular Army of the day was fully employed in manning the seacoast and frontier fortifications. ${ }^{35}$ Without further action by the Congress, President Washington relied on this statute to call up some militia and undertake military operations against Indian incursions in disputed territory, and beyond. ${ }^{36}$

Under comparably broad legislation authorizing the President to call out the militia in order to enforce the laws of the United States,

30 E. Corwin, The Prestdent: Office and Powers 130-33 (4th rev. ed. 1957). The evolution of these statutes can be traced in 10 U.S.C. $\S \S 331-34$, and 3500 (1970).

31 E. CoRwIn, supra note 30, at 134-35.

32 In re Debs, 158 U.S. 564 (1895).

33 Act of June 30, 1950, ch. 445, § 21, 64 Stat. 318, as amended, Act of June 15, 1951, ch. $138, \S 21,65$ Stat. 87 (Truman during the Korean War, 16 Fed. Reg. 6659 (1951)); 10 U.S.C. §§ 332-34 (1970) (Eisenhower during the desegregation of the Arkansas schools, 22 Fed. Reg. 7628 (1957)); 27 Fed. Reg. 9681, 9693 (1962) (Kennedy during disturbances in Mississippi); 28 Fed. Reg. 5707, 5709, 9861, 9863 (1963) (Kennedy during disturbances in Alabama); Act of Aug. 1, 1961, Pub. L. No. 87-117, § 2, 75 Stat. 242 (Kennedy during the 1961 Berlin crisis, 26 Fed. Reg. 6448 (1961)); Joint Resolution of Oct. 3, 1962, Act of Oct. 3, 1962, Pub. L. No. 87-736, § 2, 76 Stat. 710 (Kennedy during the Cuban Missile Grisis, 27 Fed. Reg. 10403 (1962)).

34 Act of Sept. 29, 1789, ch. 25, \& 5, 1 Stat. 95, 96.

$35 \mathrm{E}$. CoRwin, supra note 30 , at 131 .

36 C. Berdial, War Powers of the Executtve in the United States 61-63 (1921); H. Ward, The Departiment of War, 1781-1795 (1962); 31 Writings of Washington 268 (1939). 
President Washington put down the Whiskey Rebellion in Pennsylvania. ${ }^{37}$ In that famous and colorful instance of riotous resistance to the revenue laws of the United States in the Western counties of Pennsylvania, President Washington dispatched commissioners of conciliation to negotiate a peaceful and agreed submission of the resisters to "the general will"38 on the basis of an offer of amnesty. When their mission failed, he led a force of 12,000 to 13,000 men, drawn from the militias of New Jersey, Maryland, Virginia, and Pennsylvania, to see to it that the laws of the United States be faithfully executed. The procedures of Article IV, Section 4, of the Constitution-requiring an application of the state legislature, or the governor, when the legislature cannot be convened, before the national force is used to put down domestic violence-were ignored. Indeed Governor Mifflin of Pennsylvania urged that the use of force be delayed until it could be more conclusively demonstrated that judicial enforcement of the laws in the normal course was impossible. ${ }^{39}$

In Martin v. Mott, a case testing the legality of a fine imposed by court-martial against a member of the New York militia who refused to obey an order to rendezvous and enter the national service, the Supreme Court upheld the constitutionality of such statutes. Writing for the Court, Justice Story said:

In pursuance of this authority, the act of 1795 has provided, "that whenever the United States shall be invaded, or be in imminent danger of invasion from any foreign nation or Indian tribe, it shall be lawful for the President of the United States to call forth such number of the militia of the State or States most convenient to the place of danger, or scene of action, as he may judge necessary to repel such invasion, and to issue his order for that purpose to such officer or officers of the militia as he shall think proper." And like provisions are

37 Act of May 2, 1792, ch. 28, I Stat. 264, Section 2 provides:

That whenever the laws of the United States shall be opposed, or the execution thereof obstructed, in any State, by combinations too powerful to be suppressed by the ordinary course of judicial proceedings, or by the powers vested in the Marshals by this act, the same being notified to the President of the United States, by an Associate Justice or the District Judge, it shall be lawful for the President of the United States to call forth the militia of such State to suppress such combinations, and to cause the laws to be duly executed.

The statute provided also, in a provision subsequently dropped, that the President could use the militia in any given case for this purpose until the expiration of thirty days after the commencement of the ensuing session of Congress. See generally L. BALDWIN, WHISKEY REBEIS (rev. ed. 1965).

38 United States Senate, The Proceedings of Executive of the United States RESPECTING THE INSURGENTS, 1794 at 18 (Published by order of the Secretary of the Senate, Philadelphia 1795).

39 Id. at 58-59. 
made for the other cases stated in the constitution. It has not been denied here, that the act of 1795 is within the constitutional authority of Congress, or that Congress may not lawfully provide for cases of imminent danger of invasion, as well as for cases where an invasion has actually taken place. In our opinion there is no ground for a doubt on this point, even if it had been relied on, for the power to provide for repelling invasions includes the power to provide against the attempt and danger of invasion, as the necessary and proper means to effectuate the object. One of the best means to repel invasion is to provide the requisite force for action before the invader himself has reached the soil.

The power thus confided by Congress to the President, is, doubtless, of a very high and delicate nature. A free people are naturally jealous of the exercise of military power; and the power to call the militia into actual service is certainly felt to be one of no ordinary magnitude. But it is not a power which can be executed without a correspondent responsibility. It is, in its terms, a limited power, confined to cases of actual invasion, or of imminent danger of invasion. If it be a limited power, the question arises, by whom is the exigency to be judged of and decided? Is the President the sole and exclusive judge whether the exigency has arisen, or is it to be considered as an open question, upon which every officer to whom the orders of the President are addressed, may decide for himself, and equally open to be contested by every militiaman who shall refuse to obey the orders of the President? We are all of opinion, that the authority to decide whether the exigency has arisen, belongs exclusively to the President, and that his decision is conclusive upon all other persons. We think that this construction necessarily results from the nature of the power itself, and from the manifest object contemplated by the act of Congress. The power itself is to be exercised upon sudden emergencies, upon great occasions of state, and under circumstances which may be vital to the existence of the Union. A prompt and unhesitating obedience to orders is indispensable to the complete attainment of the object. The service is a military service, and the command of a military nature; and in such cases, every delay, and every obstacle to an efficient and immediate compliance, necessarily tend to jeopard the public interests. While subordinate officers or soldiers are pausing to consider whether they ought to obey, or are scrupulously weighing the evidence of the facts upon which the commander in chief exercises the right to demand their services, the hostile enterprise may be accomplished without the means of resistance. ... The power itself is confided to the Executive of the Union, to him who is, by the constitution, "the commander in 
chief of the militia, when called into the actual service of the United States," whose duty it is to "take care that the laws be faithfully executed," and whose responsibility for an honest discharge of his official obligations is secured by the highest sanctions. $\mathrm{He}$ is necessarily constituted the judge of the existence of the exigency in the first instance, and is bound to act according to his belief of the facts. If he does so act, and decides to call forth the militia, his orders for this purpose are in strict conformity with the provisions of the law; and it would seem to follow as a necessary consequence, that every act done by a subordinate officer, in obedience to such orders, is equally justifiable.... It is no answer that such a power may be abused, for there is no power which is not susceptible of abuse. The remedy for this, as well as for all other official misconduct, if it should occur, is to be found in the constitution itself. In a free government, the danger must be remote, since in addition to the high qualities which the Executive must be presumed to possess, of public virtue, and honest devotion to the public interests, the frequency of elections, and the watchfulness of the representatives of the nation, carry with them all the checks which can be useful to guard against usurpation or wanton tyranny. ${ }^{40}$

Similarly, early Presidents used their inherent power to deploy the armed forces, without Congressional authorization, to precipitate confrontations with the "piratical" forces of North African states, and, with and without legislation, to combat them as well.41

The most notable episode of the period dealing with the distinction between hostilities pursuant to a declaration of war and those the nation could constitutionally undertake in times of peace was the limited war with France, "John Adams' undeclared war," which arose out of French raids on American shipping and the strains and tensions of the Napoleonic Wars. ${ }^{42}$ The restraint and prndence of President Adams and of Talleyrand, opposing the forces in both countries pressing for general war, was one of the important factors preventing the full involvement of the United States in the convulsions of the European war. The domestic political controversies swirling about the episode produced the abrogation of the alliance between France and the United States, made John Adams a one-term President, destroyed the Feder-

40 Martin v. Mott, 25 U.S. (12 Wheat.) 19, 29-32 (1827). See Stewart v. Kahn, 11 Wall. 493, 506 (1870); C. ROSSITER, THE SUPREME COURT AND THE COMMANDER IN CHIEF 11-17 (1951). $41 \mathrm{~J}$. Rogers, WorLd Policing aNd THE CONSTITUTION 46-47 (America Looks Ahead No. 11, 1945); 1971 Hearings, supra note 1, at 20 (testimony of Prof. Commager), 352-60 (testimony of Senator Goldwater), 299.

42 A. DECONDE, THE QUASI-WAR 8-10 (1966). 
alist Party, and led to the election of Jefferson, and ultimately to the Louisiana Purchase. ${ }^{43}$

Although there were many who advocated a declaration of war against France, the President's resistance brought Congress to the compromise of a series of acts authorizing limited maritime warfare with France. ${ }^{44}$ Those statutes did not declare that a state of war existed, in the sense of international law. Such declarations have far-reaching consequences, both in international and domestic law, authorizing many classes of activities otherwise illegal or of doubtful legality, from censorship and blockade to the internment of enemy aliens. They have farreaching political consequences as well.

The legality of these decisions by the Congress and the President came before the courts in a series of cases concerned with captures at sea and the disposition of prize money. A number of the cases reached the Supreme Court, which decided that the provision of the Constitution regarding declarations of war was not exclusive, but that Congress could authorize hostilities in more restricted ways if it wished to do so. "Congress is empowered to declare a general war," Justice Chase said,

or congress may wage a limited war; limited in place, in objects, and in time. If a general war is declared, its extent and operations are only restricted and regulated by the jus belli, forming a part of the law of nations; but if a partial war is waged, its extent and operation depend on our municipal laws. ${ }^{45}$

The hostilities with France, the Justice declared, were "a limited, partial war," in which Congress had not made France our general enemy: "but this only proves the circumspection and prudence of the legislature." ${ }^{\prime 6}$ In Talbot $v$. Seeman, a later case dealing with the same subject, Chief Justice Marshall noted with approval that neither side had ventured to claim that hostilities could be authorized only by a declaration of war. ${ }^{47}$

In these early cases the court also sharply defended the civil control

$43 \mathrm{Id}$. at $336 \cdot 38$.

14 Act of May 28, 1798, ch. 48, 1 Stat. 561; Act of June 25, 1798, ch. 60, 1 Stat. 572; Act of July 9, 1798, ch. 68, 1 Stat. 578; Act of March 3, 1799, ch. 45, I Stat. 743 .

45 Bas v. Tingy, 4 U.S. (4 Dall.) 37,43 (1800).

$46 I d$. at $43-45$.

475 U.S. ( 1 Cranch) 1, 28-29 (1801). This is the foundation for Undersecretary of State Katzenbach's unassailable judgment that the Tonkin Gnlf Resolution was "the functional equivalent" of a declaration of war, so far as the Constitntion is concerned, although of course its effects on international politics, and in international law, are quite different. U.S. Commitments to Foreign Powers, Hearings on S. Res. 151 Before the Senate Committee on Foreign Relations, 90th Cong,, 1st Sess. 71-110, esp. at 82 (1967). 
of the military, and held an officer liable, despite authorization from the President, when the President had empowered him to commit an act not covered by the statute authorizing captures at sea. ${ }^{48}$

The constitutional boundaries sketched by this early experience have remained the guidelines of practice ever since. This is not the occasion for yet another full-scale review of the historical exercise of the power to make war by the President, with and without the support of legislation. There are now several compilations of that experience, 49 and a number of scholars have drawn a variety of conclusions from their study of the entrails. ${ }^{50}$ Of these studies, I find Professor Moore's and Professor Ratner's the most judicious, but they all deserve examination, in the perspective of Justice Jackson's comment about Pharaoh's dream.

For present purposes, however, I should refer to one of the most important of these affairs, the handling of problems relating to Florida by President Monroe and his astute Secretary of State, John Quincy Adams. No case in the long history of the debate better illustrates the interplay of Presidential and Congressional authority with regard to the use of force, and the relationship between diplomacy and military power. The credentials of Monroe and Adams as exemplars of constitutional propriety in the exercise of their functions are beyond reproach. Their practice can safely be taken, with Talbot $v$. Seeman, as a benchmark of orthodoxy in applying the principles of 1787 to the complexity of the real world.

The decay of the Spanish Empire in America was the dominant foreign policy problem of Monroe's administration. ${ }^{51}$ In one dimension, it led to his promulgation of the Monroe Doctrine, in another, to the Transcontinental Treaty of 1819 with Spain, through which Florida was annexed, the disputes over Louisiana resolved, and the western

48 Little v. Barreme, 6 U.S. (2 Cranch) 170 (1804) (per Marshall, G. J.).

$49 \mathrm{~J}$. ROGERS, supra note 41; 1971 Hearings, supra note I, at 298-316, 359-79.

50 I FALK, supra note 28; 2 FALK, supra note 28, at 597-836; 1971 Hearings, supra note 1; 1970 Hearings, supra note 1. See also R. HuLl \& J. Novogrod, LAW AND VIETNAM (1968); R. FALK, THE Six LEgAL DIMENSTONS OF tHE VIETNAM WAR (Research Monograph No. 34, Princeton University Center for International Studies, 1968), reprinted in 2 FALK, supra note 28, at 216; Moore \& Underwood, The Lawfulness of United States Assistance to the Republic of Viet-Nam, 112 CoNG. REc. 15519-67 (1966), reprinted in 5 DuQ. L. REv. 235 (1967); Jones, The President, Congress, and Foreign Relations, 29 CALIF. L. REv. 565 (1941); Mathews, The Constitutional Power of the President to Conclude International Agreements, 64 YALE L.J. 345 (1955); Ratner, The Coordinated Warmaking Power-Legislative, Executive, and Judicial Roles, 44 S. CAL. L. REv. 461 (1971); Reveley, Presidential Warmaking: Constitutional Prerogative or Usurpation?, 55 VA. L. REv. 1243 (1969).

61 H. AMmon, James Monroe, The Quest for National IDentity ch. 23-24 (1971); S. BEMIS, JOHN QUnNCY ADAMS AND THE FoundaTIONS OF AMERICAN FOREIGN Poligy ch. 15-19 (1949); P. Brooks, Diplomacy and the Borderlands, The adaMs-ONIS Treaty of 1819 (1939); J. Logan, No Transfer, An American Securitty Princtrle (1961); B. Perkins, CASTLEREAGH AND ADAMS (1964). 
boundaries of the United States fixed, so far as Spanish claims were concerned.

Monroe's overriding goal was what came to be called the Transcontinental Treaty, and the avoidance of political or military friction that might hinder the negotiations, or precipitate war either with Spain or with Great Britain, Spain's ally in the Napoleonic Wars just concluded at Vienna.

In order to move Spain to accept the path of negotiation, Monroe used both carrots and sticks. With regard to the revolutions in Latin America, he pursued a course of neutrality, despite the overwhelming popular sympathy in the United States for the revolutionaries. He carefully refrained from recognizing the new national regimes in any way until the Treaty was ratified by Spain in 1821, and sought to curb the procurement of supplies and other assistance for the revolutionaries in the United States. In Florida he employed military force twice to convince Spain that her control over Florida had in fact vanished, and that the transfer of the territory to the United States had become inevitable. In a situation of complex rivalry involving Spain, France, and Great Britain, force was used sparingly, and under close restraint, but it was used effectively by the President alone as a tool of his diplomacy.

Amelia Island-Spanish territory in the mouth of St. Mary's River-had been seized from Spain by a Scots adventurer named Gregor McGregor and a Venezuelan patriot named Louis Aury on the pretext of using it as a base for help to Venezuelan revolutionaries. Under their control, Amelia Island was an active base for privateering against Spanish shipping, and also became a haven for smugglers, slave traders, and pirates. A similar establishment had taken over Galveztown.

Monroe sent an expedition to Amelia Island in 1817, clearing out the occupants, and holding the territory without annexing it. ${ }^{52} \mathrm{He}$ buttressed his authority by referring to a Resolution and Act passed at a secret session of Congress on January 15, 1811, and withheld from publication until April 29, 1818. This legislation, too, constitutes a remarkable example of what some would regard as Congressional "delegation" of legislative power to the executive; I should prefer to regard it as an instance of cooperation between Congress and the Presidency, and the practical pooling of their powers. The Resolution provided:

Taking into view the peculiar situation of Spain, and of

$52 \mathrm{H}$. AMMON, supra note 51, at 412-18, 427-30; S. BEMIS, supra note 51, at 305-08. 
her American provinces; and considering the influence which the destiny of the territory adjoining the southern border of the United States may have upon their security, tranquillity, and commerce: Therefore,

Resolved by the Senate and House of Representatives of the United States of America, in Congress assembled, That the United States, under the peculiar circumstances of the existing crisis, cannot, without serious inquietude, see any part of the said territory pass into the hands of any foreign power; and that a due regard to their own safety compels them to provide, under certain contingencies, for the temporary occupation of the said territory; they, at the same time, declare that the said territory shall, in their hands, remain subject to future negotiation.

The statute specified:

Be it enacted by the Senate and House of Representatives of the United States of America, in Congress assembled, That the President of the United States be, and he is hereby, authorized, to take possession of, and occupy, all or any part of the territory lying east of the river Perdido, and south of the state of Georgia and the Mississippi territory, in case an arrangement has been, or shall be, made with the local authority of the said territory, for delivering up the possession of the same, or any part thereof, to the United States, or in the event of an attempt to occupy the said territory, or any part thereof, by any foreign government; and he may, for the purpose of taking possession, and occupying the territory aforesaid, and in order to maintain therein the authority of the United States, employ any part of the army and navy of the United States which he may deem necessary. ${ }^{53}$

The United States had occupied West Florida (as far east as the Pearl River) under this authority on the eve of the War of 1812. The international repercussions of this event were so ominous that Monroe, as Madison's Secretary of State, disavowed responsibility. ${ }^{54}$ At that point, of course, the inflammatory statute had not been published.

Although it is difficult to suppose that McGregor's regime constituted a "foreign power" or a "foreign government" within the intendment of Congress-indeed the United States had been assured by Great Britain that it would not take over any Spanish Colonies ${ }^{55}$-President Monroe reported to Congress on January 13, 1818:

633 Stat. 471 (1818).

54 See S. BEMIS, supra note 51 , at 314 .

$55 \mathrm{Id}$. at 304 . 
The path of duty was plain from the commencement, but it was painful to enter upon it while the obligation could be resisted. The law of 1811 , lately published, and which it is therefore proper now to mention, was considered applicable to the case from the moment that the proclamation of the chief of the enterprise was seen, and its obligation was daily increased by other considerations of high importance already mentioned, which were deemed sufficiently strong in themselves to dictate the course which has been pursued. ${ }^{56}$

The President carefully put the justification for his action on another ground as well-Spain's inability to exercise effective control over her territory, to prevent its use for purposes hostile to the interests of the United States.

For these injuries, especially those proceeding from Amelia Island, Spain would be responsible if it was not manifest that, though committed in the latter instance through her territory, she was utterly unable to prevent them. Her territory, however, ought not to be made instrumental, through her inability to defend it, to purposes so injurious to the United States. To a country over which she fails to maintain her authority, and which she permits to be converted to the annoyance of her neighbors, her jurisdiction for the time necessarily ceases to exist. The territory of Spain will nevertheless be respected so far as it may de done consistently with the essential interests and safety of the United States. ${ }^{67}$

During the same year as the Amelia Island expedition, Monroe ordered General Andrew Jackson to proceed into Spanish Florida to put down the Seminoles, who were raiding settlements in Georgia from bases in Spanish Florida, with some encouragement and technical assistance from English advisers who may or may not have represented the British government. ${ }^{58}$ The President justified his course-without benefit of any statute-under the international law allowing reprisals by way of self-defense in time of peace.

We have seen with regret that her Government has altogether failed to fulfill this obligation, nor are we aware that it made any effort to that effect. When we consider her utter inability

$662 \mathrm{~J}$. Richardson, Messages and Papers of the Presidents 24 (1898).

$57 I d$. at 24-25.

$58 \mathrm{H}$. AMMON, supra note 51 , at 414-30, 567-69; S. BEML, supra note 51, at 313-16, 326, 339. The episode gave rise to a bitter and unresolved controversy about whether Jackson had exceeded his orders, and whether Monroe's disavowal of Jackson's action was an aspect of his own diplomatic tactics. Bemis comments that "Monroe had done this sort of thing more than once before." Id. at 314. 
to check, even in the slightest degree, the movements of this tribe by her very small and incompetent force in Florida, we are not disposed to ascribe the failure to any other cause. The inability, however, of Spain to maintain her authority over the territory and Indians within her limits, and in consequence to fulfill the treaty, ought not to expose the United States to other and greater injuries. When the authority of Spain ceases to exist there, the United States have a right to pursue their enemy on a principle of self-defense. In this instance the right is more complete and obvious because we shall perform only what Spain was bound to have performed herself. To the high obligations and privileges of this great and sacred right of self-defense will the movement of our troops be strictly confined. ${ }^{58}$

Monroe was fortunate in that Castlereagh was still British Minister of Foreign Affairs during the second round of the Florida affair. Under Castlereagh, British policy was "to appease controversy and to secure if possible for all states a long interval of repose."60 Castlereagh had a quite special sense as well of the overriding long-term importance of Anglo-American friendship and collaboration, a subject to which he devoted imaginative attention. ${ }^{61}$ Despite the hypersensitive feelings of popular animosity on both sides of the ocean which plagued AngloAmerican relations then and for a long time thereafter, Castlereagh was able to pass off Andrew Jackson's invasion of Florida lightly, although Jackson had hanged two Englishmen for inciting the Indians to attack. Sir Charles Webster concludes that "in the delicate question of the Floridas ... the indefensible conduct of Andrew Jackson in 1819 produced a situation which, in the hands of a diplomatist less zealous in the cause of peace than Castlereagh, would undoubtedly have resulted in war."62 Our Ambassador in London, Richard Rush, believed that "had the English Cabinet felt and acted otherwise than it did, such was the temper of Parliament and such the feeling of the country [that] war might have been produced by holding up a finger." ${ }^{\prime \prime 3}$

Assisted by Castlereagh's forbearance, Monroe's plan had its in-

502 J. RicharDSON, supra note 56, at 31-32.

602 C. Weaster, The Foreign Policy of Castlereagh 449 (2d ed. 1934, reprinted 1963).

$61 \mathrm{Id}$. at 437 "'Certainly no other British statesman did more to lay the foundation of the hundred years peace which few in either country at that time expected and certainly many did not desire."). For example, appreciating the depth of anti-British feeling in the United States, and the general American habit of "contentious discussion", as well as Adams' prochvities in that direction, Castlereagh instructed his Ambassadors in Washington to do as much business as possible with the American government through conversations, rather than notes. Id. at 438-39. See B. PERKINs, supra note 51, at 283-98.

62 C. WEBSTER, supra note 60 , at $447-48$.

63 Id. at 450 . 
tended result. Spain decided to negotiate, in the hope of avoiding American recognition of the new regimes in South America. ${ }^{64}$

The President's careful course was complicated by the ambitions of several aspirants to the Presidency, including John C. Galhoun, William $\mathrm{H}$. Crawford, and Henry Clay. Clay denounced the invasion of Florida as an act of war by the President in violation of the Constitution, ${ }^{65}$ and excoriated Andrew Jackson, whom he rightly viewed as a rival for the Presidency. ${ }^{66}$ In the end, however, constitutional attacks in Congress on the President's authority with regard to recognition, the power to deal with territorial claims and annexations by treaty, and the hostilities in Florida were all beaten down.

The earlier history of our foreign affairs is replete with many episodes of comparable import. Without attempting to encapsulate that experience into a formula, it can be said, I believe, that its diversity reflects reasons inherent in the nature of the problem and of our polity. It matches the classification presented by Justice Jackson in his concurring opinion in the Youngstown Sheet and Tube Co. case:

Presidential powers are not fixed but fluctuate, depending upon their disjunction or conjunction with those of Congress. We may well begin by a somewhat over-simplified grouping of practical situations in which a President may doubt, or others may challenge, his powers, and by distinguishing roughly the legal consequences of this factor of relativity.

1. When the President acts pursuant to an express or implied authorization of Congress, his authority is at its maximum, for it includes all that he possesses in his own right plus all that Congress can delegate. In these circumstances, and in these only, may he be said (for what it may be worth) to personify the federal sovereignty. If his act is held unconstitutional under these circumstances, it usually means that the Federal Government as an undivided whole lacks power. A seizure executed by the President pursuant to an Act of Congress would be supported by the strongest of presumptions and the widest latitude of judicial interpretation, and the burden of persuasion would rest heavily upon any who might attack it.

2. When the President acts in absence of either a congressional grant or denial of authority, he can only rely upon his own independent powers, but there is a zone of twilight in which he and Congress may have concurrent authority, or in

64 S. BEMss, supra note 51, at 308.

65 Id. at 315 .

$68 \mathrm{H}$. AMMON, supra note 51, at 422; S. BEMIs, supra note 51, at 315. 
which its distribution is uncertain. Therefore, congressional inertia, indifference or quiescence may sometimes, at least as a practical matter, enable, if not invite, measures on independent presidential responsibility. In this area, any actual test of power is likely to depend on the imperatives of events and contemporary imponderables rather than on abstract theories of law.

3. When the President takes measures incompatible with the expressed or implied will of Congress, his power is at its lowest $\mathrm{ebb}$, for then he can rely only upon his own constitutional powers minus any constitutional powers of Congress over the matter. Courts can sustain exclusive presidential control in such a case only by disabling the Congress from acting upon the subject. Presidential claim to a power at once so conclusive and preclusive must be scrutinized with caution, for what is at stake is the equilibrium established by our constitutional system. ${ }^{67}$

The United States has used its armed forces abroad more than 150 times since 1789, and on many more occasions the President has threatened to use force. A declaration of "solemn war," fully invoking the international law of war, has been issued on only five occasions. Some of the remaining uses of force or the threat of force were undertaken pursuant to Congressional authority, although the experts debate about how many were actually responsive to prior Congressional action. In the rest, including some costly and extended campaigns, the President acted, formally at least, on his own constitutional authority.

A number of lists have been compiled, reaching different conclusions as to the number of episodes of hostilities in time of peace actually authorized in any meaningful sense by statute. ${ }^{68}$ Naturally, any President will seek to invoke a statute as partial justification for his use of armed force, as Monroe did in 1818. But in many of these cases, the statute was in fact only vaguely and imperfectly linked to the event. Professor James Grafton Rogers, in his pioneer study of the subject, reached the conclusion that there were "only a dozen or two" instances of undeclared war possibly authorized by legislation. ${ }^{69}$ In the most recent compilation of this kind, Senator Goldwater lists 153 military actions taken by the United States abroad without a declaration of war, of which he claims 63 were "arguably" initiated under prior legislative authority, 34 under a treaty, 26 under legislation, and, in the

67348 U.S. 579, 685-38 (1952).

$68 \mathrm{See}$ note 50 supra.

$69 \mathrm{~J}$. ROGERs, supra note 41 , at 79. 
case of Samoa in 1888-89 and 1899, Lebanon in 1958, and Vietnam, both under a treaty and under legislation implementing it. ${ }^{70}$ Arguably, one could count the Cuban Missile Crisis of 1962 in this final category as well, although it is more realistic to classify that incident as an example of a use of force by the President alone. ${ }^{71}$

These lists include major events: Commodore Perry's expedition to Japan and those which followed it; the array of 50,000 troops in Texas during 1865 and 1866 to support our diplomatic suggestion that France withdraw from Mexico; the participation of American forces in the hostilities following the Boxer Rebellion in China in 1900-01; the suppression of revolt in the Philippines between 1899 and 1901; the hostilities with Mexico, between 1914 and 1917; the deployments and uses of force by Wilson and Franklin Roosevelt before both World Wars; and the occupations of Haiti, the Dominican Republic, and Nicaragua, to note only the more conspicuous.

This brief evocation of history suggests two conclusions.

First, the pattern against which the Javits Bill protests is old, familiar, and rooted in the nature of things. There is nothing constitutionally illegitimate or even dubious about "undeclared" wars. We and other nations fought them frequently in the eighteenth and nineteenth centuries, as well as in the twentieth. The charge that the practice is an unconstitutional invention of this century, or of Presidents McKinley, Wilson, Franklin Roosevelt, Truman, Kennedy, and Johnson is a myth.

In the development of the foreign relations power of the United States, and of the respective roles of President and of Congress in making foreign policy, and carrying it out, it is clear that certain functions are exclusively those of the President: for example, the power to negotiate with foreign nations; the power to recognize foreign governments; and the power to deploy troops, to command them in hostilities, and to conclude an armistice. Certain authority is shared between Congress and the President; for instance, the power to issue a declaration of neutrality. President Washington proclaimed our neutrality in 1793, after a considerable constitutional debate over his authority to do so in the absence of legislation on the subject. But a confirmatory statute was passed the next year. Congress has passed other neutrality statutes from time to time, and no President has claimed that they were unconstitutional. Only Congress can declare that a "formal" or "solemn" state of war exists; provide for calling up the militia; make rules concerning

701971 Hearings, supra note 1 , at 359-79.

71 See p. 839 \& note 12 supra. 
captures on land and water, and for the government and regulation of the armed forces; and appropriate funds for the armed forces.

Congress has the last word on matters of peace and war, but the President's authority goes far beyond that to repel sudden attacks, the example Madison gave to illustrate the desirability of changing the language in Article I Section 8 from "make war" to "declare war." As Professor Ratner says:

But preeminent war-peace authority is not necessarily exclusive war-peace authority, although that congruence has been suggested by some executive and judicial statements. The ultimate decider should not always be the initial decider. Congressional action takes time. Invariably, the President confronts the problem first; may he as commander-inchief order American forces to fight without waiting for congressional authorization?

The Constitutional Convention suggested the answer by approving the motion of Madison and Gerry to amend the congressional power by 'insert[ing] 'declare,' striking out 'make' war; leaving to the Executive the power to repel sudden attacks"- -though the explanatory clause was not included in the constitutional text nor given the scrutiny of proposed inclusion. That clause thus recognized, but did not authoritatively delineate, the war-making authority of the President, implied by his role as executive and commander-in-chief and by congressional power to declare, but not make, war.

In 1787, "repel sudden attack" probably meant "resist invasion or rebellion." But constitutional policy for ensuing epochs is not congealed in the mold of 1787 referants. Such policy is derived from the long-range goals that underlie the constitutional language as illuminated by the Convention proceedings, from the implications of the language disclosed by resolution of subsequent problems, and from its function in the context of altered social needs. Aggression beyond the seas could not threaten Americans in the eighteenth century as it can in the twentieth. Underlying the constitutional language and the explanatory clause is a long-range purpose that authorizes the President to protect Americans from external force in an emergency.

Listing eight categories of purely Presidential use of force in time of peace under circumstances recognized as legitimate by international law, Ratner concludes:

The amorphous distinction between offense and defense does not effectively delineate the scope of the President's emergency war power. In a world where increasingly mobile weapons enhance the advantage of military initiative, the 
distinction turns, for the most part, on an appraisal of motives and intentions. With his heavy load of responsibility, the President may sometimes conclude that offense is the best defense. As the foregoing examples indicate, presidentiallyauthorized hostilities are always ostensibly "defensive." And, though his characterization may be debatable, the President must necessarily be accorded a broad discretion. ${ }^{72}$

As to sustamed hostilities in the absence of a declaration of war, the pattern of constitutional practice offers no sharp and formal lines. There are instances of Congressional action to authorize undeclared wars, and instances in which, nominally at least, Congress was silent. The practice, however, does justify a second general conclusion: It is an illusion to suppose, in the nature of our political system, that the formal silence of Congress on some of these occasions when force was used extensively represents a genuine opposition between Congress and the Presidency. The power of the United States to employ force or to carry on any other sustained policy can be exercised in fact only when Congress and the President cooperate, however unwillingly. The silences and the tacit arrangements of American politics are often more important than its nominal dispositions and documents.

In the closing days of his second Administration, for example, Cleveland, repudiated by his party, was functioning as a lame-duck President, waiting to transfer his office to McKinley. Congress, meanwhile, exercised by the revolution in Cuba and no doubt emboldened by the inherent weakness of the President's position, took a number of initiatives.

The Senate Foreign Relations Committee let it be known that it was proposing to report out the Cameron Resolution, which purported to recognize the independence of the Republic of Cuba. Cleveland's redoubtable Secretary of State, Richard Olney, commented:

It is, perhaps, my duty to point out that the resolution, if passed by the Senate, can probably be regarded only as an expression of opinion by the eminent gentlemen who voted for it in the Senate, and if passed by the House of Representatives, can only be regarded as another expression of opimion by the eminent gentlemen who vote for it in the House.

The power to recognize the so-called Republic of Cuba as an independent state rests exclusively with the Executive.

A resolution on the subject by the Senate or by the House, by both bodies or by one, whether concurrent or joint, is

72 Ratner, supra note 50, at 466-69." 
inoperative as legislation, and is important only as advice of great weight voluntarily tendered to the Executive regarding the manner in which he shall exercise his constitutional functions.

The operation and effect of the proposed resolution, therefore, even if passed by both houses of Congress by a two-thirds vote, are perfectly plain. It may raise expectations in some quarters which can never be realized. It may inflame popular passions, both in this country and elsewhere; may thus put in peril the lives and property of American citizens who are resident and traveling abroad, and will certainly obstruct and perhaps defeat the best efforts of this Government to afford such citizens due protection.

But except in these ways, and unless the advice embodied in the resolution shall lead the Executive to revise conclusions already reached and officially declared, the resolution will be without effect and will leave unaltered the attitude of this Government toward the two contending parties in $\mathrm{Cuba}^{\mathbf{7 3}}$

The Cameron Resolution was reported out of Committee, but never put to a vote.

In the same period, a number of Congressional leaders called on President Gleveland to discuss an "important matter." They said,

"We have about decided to declare war against Spain over the Cuban question. Conditions are intolerable."

Mr. Gleveland drew himself up and said, "There will be no war with Spain over Cuba while I am President."

One of the members flushed up and said angrily, "Mr. President, you seem to forget that the Constitution of the United States gives Congress the right to declare war."

$\mathrm{He}$ answered, "Yes, but it also makes me Commanderin-Chief, and I will not mobilize the army. I happen to know that we can buy the Island of Cuba from Spain for $\$ 100,000,000$, and a war will cost vastly more than that and will entail another long list of pensioners. It would be an outrage to declare war."74

The project died.

On the other side of the coin, the formal arrangements for carrying on the Korean War give a misleading impression. When South Korea was invaded in 1950, President Truman met several times with the Congressional leadership, as is customary, to consult with them about policy. As Dean Acheson reports the meeting of June 30:

73 H. James, Richard OlNey and His Public Service 168-69 (1923).

742 R. McElroy, Grover Cleverdand, the MAN AND the Statesman 249-50 (1923). 
At eleven o'clock I returned to the White House for a meeting with congressional leaders, taking Foster Dulles, just back from Tokyo, with me. The congressional group was perhaps twice as large as the one at the Tuesday meeting. The President reported the situation in Korea, reviewed the actions previously taken by the United Nations Security Council and the United States Government, and the orders he had issued that morning. A general chorus of approval was interrupted by, I think, Senator Kenneth Wherry questioning the legal authority of the executive to take this action. Senator Alexander Smith suggested a congressional resolution approving the President's action. The President said that he would consider Smith's suggestion and asked me to prepare a recommendation. The meeting ended with Representative Dewey Short stating that Congress was practically unanimous in its appreciation of the President's leadership. Short was a Republican from the President's home state of Missouri and ranking minority member of the Armed Services Committee. ${ }^{75}$

After this meeting, according to Dean Acheson's recollection, Senator Taft, the Republican leader in the Senate, offered to support any Resolution the President should propose to put Congress firmly on record behind his actions, and those of the Security Council. ${ }^{76}$

A draft Resolution was prepared. Senator Smith asked for a delay while he took care of some urgent political problems in New Jersey. Acheson's account continues:

My recommendation was that the President make a full report on the Korean situation to a joint session of Congress. This would, of course, be largely formal but would bring the whole story together in one official narrative and meet the objection of some members that information had come to them only through the leaders and the press. I also recommended that the President should not ask for a resolution of approval, but rest on his constitutional authority as Commander-in-chief of the armed forces. However, we had drafted a resolution commending the action taken by the United States that would be acceptable if proposed by members of Congress.

In the ensuing discussion it appeared that the two houses of Congress had just recessed for a week and the President was unwilling to call them back. Senator Lucas, General Bradley, and Secretary Johnson were opposed to both recommendations: to the report because it would come too long after the events to stand by itself and had better accompany a request

75 D. Acheson, Present at the Greation 413 (1969).

76 Conversations of author with Dean Acheson, 1953, 1967. 
for money and necessary powers; and to the resolution because the vast majority in Congress were satisfied and the irreconcilable minority could not be won over. They could, however, keep debating and delaying a resolution so as to dilute much of its public effect. The others were divided. My sympathies lay with the Lucas-Bradley view. So apparently did the President's, for he put off a decision until the "Big Four" (the presiding officers and majority leaders of both houses) would be back after the recess. By then we were pretty well won over to Senator Lucas' view.

There has never, I believe, been any serious doubt-in the sense of nonpolitically inspired doubt-of the President's constitutional authority to do what he did. The basis for this conclusion in legal theory and historical precedent was fully set out in the State Department's memorandum of July 3, 1950, extensively published. ... But the wisdom of the decision not to ask for congressional approval has been doubted. To have obtained congressional approval, it has been argued, would have obviated later criticism of "Truman's war." In my opinion, it would have changed pejorative phrases, but little else. Congressional approval did not soften or divert the antiwar critics of Presidents Lincoln, Wilson, and Roosevelt. What inspired the later criticism of the Korean war was the long, hard struggle, casualties, cost, frustration of a limited and apparently inconclusive war, and-most of all-the determination of the opposition to end seemingly interminable Democratic rule.

Nevertheless, it is said, congressional approval would have done no harm. True, approval would have done none, but the process of gaining it might well have done a great deal. July - and especially the first part of it-was a time of anguishing anxiety. As American troops were committed to battle, they and their Korean allies under brutal punishment staggered back down the peninsula until they maintained only a precarious hold on the coastal perimeter around Pusan. An incredulous country and world held its breath and read the mounting casualties suffered by these gallant troops, most of them without combat experience. In the confusion of the retreat even their divisional commander, Major General William F. Dean, was captured. Congressional hearings on a resolution of approval at such a time, opening the possibility of endless criticism, would hardly be calculated to support the shaken morale of the troops or the unity that, for the moment, prevailed at home. The harm it could do seemed to me far to outweigh the little good that might ultimately accrue. 
The President agreed, moved also, I think, by another passionately held conviction. His great office was to him a sacred and temporary trust, which he was determined to pass on unimpaired by the slightest loss of power or prestige. This attitude would incline him strongly against any attempt to divert criticism from himself by action that might establish a precedent in derogation of presidential power to send our forces into battle. The memorandum that we prepared listed eighty-seven instances in the past century in which his predecessors had done this. And thus yet another decision was made. ${ }^{77}$

This experience did not prevent Senator Taft, at a later date, from attacking the constitutionality of Truman's decision to fight in Korea under his authority as President to ensure that the treaties of the United States be faithfully executed as the supreme law of the land. ${ }^{8}$

\section{The Immediate Context of the Javits Bill}

The modern controversies over the division of constitutional authority between Congress and the President with respect to military operations have a special intensity, which reflects the scale of American involvement in world politics since 1940, and the shock and controversy resulting from Korea and Vietnam.

Of course the nation faces foreign policy problems today altogether different from those it faced in 1800 , or even in 1900 . Between 1815 and 1914, we lived safely within a system of general peace maintained by the Concert of Europe. Our diplomacy, while active, was peripheral to the overriding problem of maintaining the balance of power which allowed the entire world to enjoy an extraordinary century without large scale war. That system broke down in 1914, and collapsed finally in 1945, imposing on the United States for the first time direct responsibility for protecting its primal security as a nation by direct and continuous involvement in world politics.

It does not follow that we live in a world where Presidential primacy in the making of American foreign policy is inevitable, or desirable. All but a few believe that under the Constitution Congress should play an active, responsible, and indeed the ultimate role in making foreign policy. Certainly I am no friend of unlimited Presidential discretion to decide when the nation should go to war.

77 D. Acheson, supra note 75, at 414-15. See also $2 \mathrm{H}$. Truntan, Memoirs, Years of TRLAI AND Hope 331-48, 409-10, 420-26, 478 (1956).

78 Taft, The Place of the President and Congress in Foreign Policy, in A ForeIGN POLICY FOR AMERICANS ch. 2 (1951), reprinted in 1970 Hearings, supra note 1 , at 557. 
The circumstances of modern world politics, however, require Presidents to act quickly, and often alone. They continue to face the delicate problems of diplomatic judgment which John Adams confronted in seeking to protect American shipping without full scale war with France; which Madison and Monroe faced in trying to solve the problem of Florida without precipitating war with Spain or England; which Gleveland met in seeking to avoid war with Spain over Cuba; and comparable dilemmas which have plagued nearly all our Presidents.

That fact does not preclude the possibility of effective cooperation between Congress and the President. Congress should be able to act effectively both before and after moments of crisis or potential crisis. It may join the President in seeking to deter crises by publicly defining national policy in advance, through the sanctioning of treaties or other legislative declarations. Equally, Congress may participate formally in policymaking after the event through legislative authorization of sustained combat, either by means of a declaration of war, or through legislative action having more limited legal and political consequences. Either of these devices, or both in combination, should be available in situations where cooperation between the two branches is indicated at many points along an arc ranging from pure diplomacy at one end to a declaration of war at the other.

The constitutional storm which has given rise to the Javits Bill began shortly after the Korean War. As noted earlier, the United States acted formally in Korea under the United Nations Charter, viewed as a Treaty of the United States, and under the President's inherent constitutional powers in carrying out that Treaty obligation, without benefit of a formal, direct vote by Congress.

The legal posture of American intervention in Korea aroused genuine constitutional concern. ${ }^{70}$ There was anxiety at the apparent authority of the Security Council, an international body sitting in New York, to take a vote that would bind the United States to go to war - concern about sovereignty, and concern, too, about the seemingly unlimited powers of the President in relation to those of the Congress. There was, of course, repeated Congressional support for various aspects of the Korean War and for the war itself through appropriations statutes and otherwise. But the war became unpopular and was a decisive factor both in Truman's decision not to seek a second term and in the elections of 1952.

79 See pp. 867-870 \& note 77 supra. 
Although Senator Bricker's proposals for a constitutional amendment failed, President Eisenhower responded to the outcry by developing the practice of making many treaties embodying national security commitments, and obtaining Congressional Resolutions authorizing him to employ the armed forces in the Mediterranean, and the Formosa Straits, a practice pursued thereafter with regard to Berlin, Cuba, and Vietnam..$^{80}$ These formal modes of cooperation between Congress and the Presidency constitute the immediate legal context of our involvement in Vietnam, and of the debates which have resulted in the Javits Bill.

From the point of view of the constitutional argument over the respective war powers of the President and Congress, our engagement in Vietnam rests first on the South East Asia Collective Defense Treaty, generally known as SEATO. The Treaty was negotiated and ratified shortly after the Geneva Conference of 1954, as part of a general strategy of containing the consequences of French defeat in Indo-China, and limiting the outward thrust of Communist bids for power in Malaysia, the Philippines, and Korea, as well as in Indo-China. ${ }^{81}$ Under that Treaty, the United States, Australia, France, New Zealand, Pakistan, the Philippines, Thailand, and the United Kingdom became guarantors against direct and indirect aggression not only for the three non-communist successor states of French Indo-China, but for South East Asia as a whole.

In the preamble to the Treaty, the signatories declared their sense of unity publicly and formally, as notice to "any potential aggressor" in the area. In Article II, they undertook, "separately and jointly," to "maintain and develop their individual and collective capacity to resist armed attack and to prevent and counter subversive activities

so See note 9 supra. President Johnson has said,

I was determined, from the time I became President, to seek the fullest support of Congress for any major action that I took, whether in foreign affairs or in the domestic field. I believed that President Truman's one mistake in courageously going to the defense of South Korea in 1950 had been his failure to ask Congress for an expression of its backing. He could have had it easily, and it would have strengthened his hand. I had made up my mind not to repeat that error, but always to follow the advice I myself had given President Eisenhower.

L. Jornson, supra note 13, at 115 (1971).

In the event, of course, Dean Acheson's judgment, pp. 868-870 supra turned out to rest on a more realistic appreciation of human fallibility. "Johnson's War" joined "Truman's War" and "John Adams' Undeclared War" in the demonology of American politics. In 1964 and 1965, Johnson often said that he knew that if he wanted Congress with him at the landing, it should be with him at the take-off. He remarked later that he had not counted on the availability of parachutes.

81 Southeast Asia Collective Defense Treaty, Sept. 8, 1954, [1955] 1 U.S.T. 81, T.I.A.S. No. 3170. See G. Cooper, The Lost Grusade: AMERICA in VIETNaM (1970); R. RandLe, GENEVA 1954 (1969). 
directed from without against their territorial integrity and political stability." The first paragraph of Article IV provides that "each party recognizes that aggression by means of armed attack in the treaty area against any of the Parties" (or against states or territories designated in the protocol to the Treaty, which lists Laos, Cambodia, and what is now South Vietnam, if they choose to be protected) "would endanger its own peace and safety, and agrees that it will in that event act to meet the common danger in accordance with its constitutional processes" (italics added). In contrast to the individual and categorical obligation of paragraph 1, paragraph 2 provides that if threats or problems other than armed attacks arise, "the Parties shall consult immediately in order to agree on the measures which should be taken for the common defense." 82

While SEATO has had a checkered history as an international organization, the Treaty did put the United States squarely into the Southeast Asian picture. As Chester Cooper points out, "it was a commitment, albeit one considerably less robust than was originally conceived, to involve the United States in the security and economic development of the countries in that area-a part of the world which until 1954 had been pretty much left to the British and the French."83

The United States government has based its policy in Vietnam on the SEATO Treaty, as well as on South Vietnam's inherent right of self-defense, and our right under the U.N. Charter to assist South Vietnam in that defense. ${ }^{84}$ For example, President Eisenhower noted in

82 For the formal relation between SEATO and the Geneva arrangements see R. RANDLE, supra note 81, at 539-41.

83 C. COOPER, supra note 81 , at 114.

84 In the perspective of international law, two related arguments are raised against the American course in Vietnam:-(1) the Vietnamese war is a civil war, internal to the conceptual state, or nation, of "Vietnam"; and (2) the North Vietnamese attack on South Vietnam is justified because no referendum on unifying North and South Vietnam was held in 1956, as contemplated by the Declaration issued at the end of the Geneva Conference in 1954 .

The war in Vietnam is not a civil war, but an international war. Two Vietnamese states emerged from the Geneva Conference, and the years of fighting which preceded it. It was elearly understood at Geneva that Vietnam, like Germany and Korea, was a nation divided against its will by the circumstances of the Cold War, and that its reunification, like that of Germany and Korea, would have to come through political agreement, not war.

C. COOPER, supra note 81, at 98, 100; R. RANDLE, supra note 81 , at 429 , 444-46. North and South Vietnam are political entities-two states within a single nation, to borrow Chancellor Brandt's phrase-entitled to all the normal rights of states, and entitled also to the protection of the United Nations Charter.

This protection was not suspended by the unsigned Declaration issued at the end of the Geneva Conference-a document that had even nominal support only from four of the nine participants in the Conference. That document cannot authorize North Vietnam to attack South Vietnam, or, if one prefers, to assist revolutionaries within South Vietnam, because no referendum on the possible unification of the two states was held in 1956 . South Vietnam did not accept the Declaration of Geneva, and the United States formally 
a formal statement in 1957 that South Vietnam is covered by the Treaty, and said "that aggression or subversion threatening the political independence of the Republic of Vietnam would be considered as endangering peace and stability" within the meaning of that document. ${ }^{85}$ The theme has been sounded in official speeches and statements ever since. Both Congress and four Presidents have repeatedly concluded that North Vietnam's participation in the war against South Vietnam constitutes "armed attack" within the meaning of Article IV of the Treaty.

The commitment of SEATO was later reiterated, so far as the United States is concerned, in the Tonkin Gulf Resolution, passed in 1964. That Resolution, which has since become a matter of considerable controversy, says:

The United States regards as vital to its national interest and to world peace the maintenance of international peace and security in southeast asia. Consonant with the Constitution of the United States and the Charter of the United Nations and in accordance with its obligations under the Southeast Asia Collective Defense Treaty, the United States is, therefore, prepared, as the President determines, to take all necessary steps, including the use of armed force, to assist any member of protocol state of the Southeast Asia Collective Defense Treaty requesting assistance in defense of its freedom. ${ }^{86}$

The Resolution stated the full support and approval of Congress for the President to take all necessary measures to protect our own forces, "and to prevent further aggression."

In a colloquy with Senator Cooper, Senator Fulbright explained that the passage of this Resolution fulfilled the provision of the SEATO Treaty requiring each nation to carry out its obligations under the

refused to adhere to it. In any event, the failure to hold such elections, or otherwise to unify the two halves of a divided country by political means, could hardly justify its unification by force, even where unification has been promised by the Great Powers, as is the case for Korea and Germany as well as Vietnam. This is precisely what the Security Council decided in 1950 when it held that North Korea had violated the Charter by attacking South Korea; that South Korea was therefore justified in exercising its inherent rights of self-defense assured by Article 51 of the Charter; and that other nations were allowed-indeed required-to assist South Korea collectively in that defense. See E. Rostow, PEAGe IN THE Balance ch. 5 (1972, in press); E. Rostow, LAw, POWER and the PURSUIT of PEACE 60-67 (1968). For further examination of the justification for American policy in Vietnam as a matter of international law, see J. MOORE, LAW AND INDOGHINA WAR (1972); and materials cited in notes $28 \& 50$ supra.

85 Foreign Policy and Foreign Aid, 36 Dep't State BulL. 851, 852 (1957). See also Address by President Eisenhower, The Importance of Understanding, 40 DEP'T STATE BuLI. 579-83 (1959); Senate COMM. ON FORETGN RELations, Background INFORMation Relating to Southeast ASIA AND VIETnam, 91st Cong., 2d Sess. 184-91, 208-14, 218-35 (Comm. Print 6 th rev. ed. 1970).

86 H.R.J. Res. of Aug. 10, 1964, Pub. L. No. 88-408, § 2, 78 Stat. 384. Section 3 of the Resolution provides that it may. be terminated by concurrent resolution of the Congress. 
Treaty through its own constitutional processes. That exchange is so central to the present debate as to require its full reproduction here:

MR. COOPER. I ask these questions for two reasons: One is to get the opinion of the chairman of the Foreign Relations Committee and of the chairman of the Armed Services Committee as to the extent of the powers that are given to the President under the resolution. The second is to distinguish between a situation in which we act in defense of our own forces, in which without question we would risk war, and the commitment to defend South Vietnam.

My first question goes to the first section of the resolution -the operative part which, as the chairman has said, applies to any armed attack or any aggression directed against the forces of the United States.

MR. FULBRIGHT. That is correct.

MR. COOPER. In that case, of course, we confirm the power that the President now has to defend our forces against an immediate attack.

MR. FULBRIGHT. The Senator is a very distinguished lawyer, and I therefore hesitate to engage in a discussion with him on the separation of powers and the powers of the President. We are not giving to the President any powers he has under the Constitution as Commander in Chief. We are in effect approving of his use of the powers that he has. That is the way I feel about it.

MR. COOPER. I understand that, too. In the first section we are confirming the powers.

MR. FULBRIGHT. We are approving them. I do not know that we give him anything that he does not already have. Perhaps we are quibbling over words.

MR. COOPER. We support and approve his judgment.

MR. RUSSELl. Approve and support.

MR. FULBRIGHT. Approve and support the use he has made of his powers.

MR. COOPER. The second section of the resolution goes, as the Senator said, to steps the President might take concerning the parties to the Southeast Asia Collective Defense Treaty and the countries under the protocol-which are, of course, Laos, Cambodia, and South Vietnam. The Senator will remember that the SEATO Treaty, in article IV, provides that in the event an armed attack is made upon a party to the Southeast Asia Collective Defense Treaty, or upon one of the protocol states such as South Vietnam, the parties to the treaty, one of whom is the United States, would then take such action as might be appropriate, after resorting to their constitutional processes. I assume that would mean, in the case of the United 
States, that Congress would be asked to grant the authority to act.

Does the Senator consider that in enacting this resolution we are satisfying that requirement of article IV of the Southeast Asia Collective Defense Treaty? In other words, are we now giving the President advance authority to take whatever action he may deem necessary respecting South Vietnam and its defense, or with respect to the defense of any other country included in the treaty?

MR. FULBRIGHT. I think that is correct.

Mr. COOPER. Then, looking ahead, if the President decided that it was necessary to use such force as could lead into war, we will give that authority by this resolution?

MR. FULBRIGHT. That is the way I would interpret it. If a situation later developed in which we thought the approval should be withdrawn, it could be withdrawn by concurrent resolution. That is the reason for the third section.

MR. COOPER. I ask these questionstions.

MR. FULBRIGHT. The Senator is properly asking these ques-

MR. COOPER. I ask these questions because it is well for the country and all of us to know what is being undertaken.

Following up the question I have just asked and the Senator's answer, I present two situations that might arise.

Under the first section of the joint resolution, the President is supported and approved in action he may take "to repel any armed attack against the forces of the United States and to prevent further aggression."

It has been reported that we have already sent our planes against certain ports in North Vietnam. I am sure that the reason is "to repel armed attack and to prevent further aggression" against U.S. forces.

Under section 2, are we now providing the President, if he determines it necessary, the authority to attack cities and ports in North Vietnam, not primarily to prevent an attack upon our forces but, as he might see fit, to prevent any further aggression against South Vietnam?

MR. FULBRIGHT. One of the reasons for the procedure provided in this joint resolution, and also in the Formosa and Middle East instances, is in response, let us say, to the new developments in the field of warfare. In the old days, when war usually resulted from a formal declaration of war-and that is what the Founding Fathers contemplated when they included that provision in the Constitution-there was time in which to act. Things moved slowly, and things could be seen developing. Congress could participate in that way.

Under modern conditions of warfare-and I have tried to 
describe them, including the way the Second World War developed-it is necessary to anticipate what may occur. Things move so rapidly that this is the way in which we must respond to the new developments. That is why this provision is necessary or important. Does the Senator agree with me that this is so?

MR. COOPER. Yes, warfare today is different. Time is of the essence. But the power provided the President in section 2 is great.

MR. FULBRIGHT. This provision is intended to give clearance to the President to use his discretion. We all hope and believe that the President will not use this discretion arbitrarily or irresponsibly. We know that he is accustomed to consulting with the Joint Chiefs of Staff and with congressional leaders. But he does not have to do that.

MR. COOPER. I understand, and believe that the President will use this vast power with judgment.

MR. FULBRIGHT. He intends to do it, and he has done it.

MR. COOPER. I do not wish to take more time now, because the distinguished Senator from Georgia wishes to speak, and I want to hear him.

MR. FULBRIGHT. I have no doubt that the President will consult with Congress in case a major change in present policy becomes necessary.

MR. COOPER. I will speak further later in the day. I wish to say this now: I know it is understood and agreed that in the defense of our own ships and forces any action we might take to repel attacks could lead to war, if the Vietnamese or the Chinese Communists continued to engage in attacks against our forces. I hope they will be deterred by the prompt action of the President.

We accept this first duty of security and honor. But I would feel untrue to my own convictions if I did not say that a different situation obtains with respect to South Vietnam. I know that a progression of events for 10 years has carried us to this crisis. Ten years have passed and perhaps the events are inevitable now, no one can tell. But as long as there is hope and the possibility of avoiding with honor a war in southeast Asia - a conflagration which, I must say, could lead into war with Communist China, and perhaps to a third world war with consequences one can scarcely contemplate today-I hope the President will use this power wisely with respect to our commitments in South Vietnam, and that he will use all other honorable means which may be available, such as consultations in the United Nations, and even with the Geneva powers.

We have confidence in the President and in his good judgment. But I believe we have the obligation of understanding 
fully that there is a distinction between defending our own forces, and taking offensive measures in South Vietnam which could lead progressively to a third world war.

MR. FULBRIGHT. The question concerns the kind of actions taken in this instance. I think the President took action that is designed to accomplish the objective the Senator from Kentucky has stated. That is what I have tried to make clear. I join in the Senator's hope that all-out war can be avoided.87

Whether Congressional action of this kind is necessary under the American Constitution, or whether the President can properly act alone in carrying out Treaty obligations, as President Truman did in Korea, remains a matter for debate. As Senator Cooper writes in his candid and thoughtful statement of Individual Views with respect to the Javits Bill:

I consider it important that the words "constitutional processes" used in existing and in any future bilateral or multilateral defense treaties to which the United States may become a party, be interpreted in S. 2956 to affirmatively require that the engagement of United States forces in hostilities beyond the emergency authority of the Executive shall not be undertaken without the approval of the Congress. This is the purpose of the first amendment which I have discussed above in this statement.

Existing post-World War II defense treaties are under attack today, and I think it proper to recall the background and events under which they were entered into following World War II, and to state that at the time they had practically unanimous support of the Congress, the news media, and the people.

The collapse of Nazi Germany brought the Soviet armies into Eastern Europe at the close of World War II. The Communist coup in Czechoslovakia in 1948, the fall of Nationalist China, the attack upon South Korea and the possibility of a thrust from Communist China toward Southeast Asia, caused great concern in the United States, Europe and Southeast Asian countries as to their security and led to the negotiation of the treaties. There were 8 of these treaties and they included 43 nations. Among them are NATO, SEATO, ANZUS, Inter-American, and bilateral treaties with Japan, Korea, the Philippines and Nationalist China.

While these treaties differ in certain respects-particularly NATO, which recites that an attack upon a vast area defined by the treaty shall be considered an attack upon all the parties-they are similar in substance. Typical is the language

87110 CONG. REC. 18409-10 (1964). 
of the SEATO Treaty, which provides in Article 1, Section 1, that:

Each Party recognizes that aggression by means of armed attack in the treaty area against any of the Parties... would endanger its own peace and safety, and agrees that it will in that event act to meet the common danger in accordance with its constitutional process.

The term "constitutional processes" is not defined in the treaties. And the reports of the committees and the debates in the Congress on its meaning show disagreement, without definition. It was not settled whether the requirement of "constitutional processes" meant that the President, acting as Commander-in-Chief, could commit the forces of the United States to the military assistance of another treaty party, or meant that the President should consult with the Congress to determine jointly whether the commitment of military forces was essential to the security of the United States as well as that of other parties to the treaty and that the Executive would not commit our forces until the Congress had given its approval, either by a declaration of war or by a joint resolution.

During the Senate's consideration of the Korean Defense treaty in 1954, several Senators, including myself, but particularly Senator John Stennis and former Senator Watkins of Utah, insisted that the proper interpretation of the term "constitutional processes" as used in that treaty required the authorization of the Congress. There was no authoritative answer. I support such an interpretation.

The record of the hearing before the Senate Foreign Relations Committee and the debates in the Senate disclose that all of these treaties were approved by the Senate Foreign Relations Committee and the Senate with little opposition and without precisely determining the interpretation of "constitutional processes" and the commitment of the United States. Resolutions approved by Congress-some implementing certain of these treaties-uniformly provided to the Executive broad powers to involve the armed forces of the United States in hostilities, whether in the administrations of Presidents Truman, Eisenhower, Kennedy or Johnson. President Eisenhower was particularly insistent upon Congressional approval for military movements that might have involved the United States in a war. He was supported by Secretary of State John Foster Dulles who stated, in response to Committee inquiries, that the Executive would seek approval by the Congress for any such involvement. No involvement in war occurred during the Administration of President Eisenhower. 
In fact, reservations offered in Committee and on the Senate floor during the consideration of several of these treaties, and amendments offered to Executive resolutionsFormosa, Middle East, Berlin, Guba and Tonkin Gulf-to prohibit the use of the armed forces of the United States without Congressional approval were consistently opposed and rejected in the Foreign Relations Committee and in the Senate.

I present these facts because I do not concur in one underlying theme of the Committee's report-which was never discussed in Committee and never voted on-that the Executive has taken from the Congress its powers. The record, if studied, discloses that the Congress, particularly since World War II, has not only acceded to but has supported Executive resolutions requesting Congressional authority to use the armed forces of the United States, if necessary, in hostilities.

These are settled facts of history. We can change our course but we cannot revise and rewrite history. ${ }^{88}$

Naturally, in facing an issue of this kind, both Presidents and members of Congress will be sensitive to their prerogatives. No President will, or should, acquiesce in a diminution of the historical powers of his office. And Congress can be expected to insist, as best it can, on the claims which Senator Cooper puts forward. Thus far we have been able to devise forms of language which accommodate these conflicting principles in a pattern of cooperative action involving both Congress and the Presidency. For every participant, however proud, thoroughly understands, as Justice Jackson said, that the United States speaks with a stronger voice when the President and Congress act together.

Thus the Senate's action in consenting to the SEATO Treaty, and Congress' action in passing the Tonkin Gulf Resolution and several similar statutes, meant that in Vietnam Congress and the Presidency had acted together, both in giving solemn advance notice of American policy towards Vietnam, and in reaffirming that policy after hostilities began. So far as the constitutional proprieties are concerned, the American involvement in Vietnam occurred through a procedure which is a model for democratic decisionmaking. There is therefore no basis for the charge that the American course of action in Vietnam violates the

88 WAR POWERs, supra note 1 , at $30-32$. The unsettled state of doctrine analyzed by Senator Cooper permitted some to indulge in a meaningless gesture of protest against the war in Vietnam by voting for the repeal of the Tonkin Gulf Resolution, while leaving the SEATO Treaty untouched. By accepting Truman's view of the matter-for the moment, at least-they could enjoy the best of both worlds. S. Con. Res. 64, 91st Cong., 2d Sess., 116 ConG. REc. 23496, 23710-46, 23965 (1970); SENATE CoMm. ON ForetGN RELATIONS, TERMINAtion of South EAST Asia Resolution, S. REP. No. 91-872, 91st Cong., 2d Sess. 13 (1970). 
internal law of the United States, or arrogates power to the President at the expense of Congress. In this regard, the constitutional practice with regard to Vietnam was more punctilious and complete in pooling Congressional and Presidential power than that nsed in Korea. ${ }^{89}$

\section{A. Sauve Qui Peut-by Parachute: Exorcising the Tonkin Gulf Resolution}

Many attempts have been made to avoid the force of these facts in support of the claim that the actions of the United States in Vietnam are unconstitutional.

We can put to one side the erroneous view that Congress can authorize sustained hostilities only by "declaring" war. While this position has no support in constitutional history, it is surprisingly widespread in public opinion, and strongly colors popular, and even professional attitudes towards "undeclared" war.

A more serious basis for the charge of unconstitutionality with regard to Vietnam is the argument (a) that the constitutional processes of the United States require action by Congress as well as by the President before the obligation of the SEATO Treaty could be translated into action; and (b) that the Tonkin Gulf Resolution and other legislation of like effect can be ignored as public acts of the United States because Congress did not intend to authorize what was done, or was insufficiently informed, or acted hastily in passing these resolutions, or was deceived by the Executive Branch.

The first part of this contention is settled by Senator Cooper's analysis, quoted above. In passing the Tonkin Gulf Resolution, Congress was explicitly aware that it was closing the constitutional gap arguably left open by the procedure adopted in the Korean case, in

89 Professor Bickel has suggested elsewhere that President Truman's action in Korea had another constitutional base, the President's power to repel sudden attacks, which might distinguish Korea from Vietnam.

I would add about Korea that it was a massive attack by organized armies across

a previously established border. We had troops with a full-scale establishment in

Japan, right across the ditch. Thus, the surmise that this was a venture which

threatened the safety of an established American military presence seemed plausible.

The Power to Make War: A Debate Between Alexander M. Bickel and Eugene $\nabla$. Rostow, 18 YalE L. REP. 3, 6 (1971-72). See also 1971 Hearings, supra note 1, at 552. This argument contradicts Professor Bickel's testimony before the Senate Foreign Relations Committee, and the theory and language of the Javits Bill, which would admit a Presidential power to repel sudden attacks only against the territory or armed forces of the United States, not those of the South Korea. Id. at 553, 558-59, 566, 572, 574. In any event, Professor Bickel's new contention surely proves too much. In 1968, it would have authorized the President to use force in Czechoslovakia, a country separated from the NATO military establishment in Germany by a land boundary-not even a "ditch." 
which, nominally at least, the President acted alone in carrying out the United Nations Charter, viewed as a Treaty of the United States. Whether Congressional action was or was not constitutionally necessary to authorize the use of American military power in carrying out the commitments of the United States under the SEATO Treaty, it was made available, so that under either theory-that of President Truman or that of Senators Cooper and Stennis-the full array of American constitutional authority was formally deployed behind the campaign in Vietnam.

In his attacks on the constitutionality of the Vietnam War, Professor Velvel accepts this critical fact. He writes,

As the text of the Resolution illustrates, any reasonable man must concede that, if one considers only the langnage of the Resolution and totally ignores the congressional intent expressed in its ample legislative history, its language is broad enough to authorize the President, in his sole discretion, to fight a large scale land, sea and air war on the continent of Asia.90

Like several other scholars, however, Professor Velvel contends that even where legislation is unambignous, it is permissible, indeed necessary, to refer to its legislative history to determine its true scope. Selectively culling over the messages and debates of the time, and the explanatory comments made later by Senators who came to regret their vote, Velvel urges that the Resolution be given a narrower reading, as authorizing the President only to respond to the immediate attack which precipitated the Resolution.

This argument cannot survive a reasonably dispassionate reading of the debates in the House and Senate. Many were troubled. A few were opposed. All hoped another Korea could be avoided. But all who spoke knew exactly what they were authorizing, or opposing. As Senator Javits said, "We who support the joint resolution do so with full knowledge of its seriousness and with the understanding that we are voting [for] a resolution which means life or the loss of it for who knows how many hundreds or thousands . . . ."91 "Who knows how

90 Velvel, The War in Vietnam: Unconstitutional, Justiciable, and Jurisdictionally Attackable, 16 KANSAS L. REV. 449, 473 (1968), reprinted in 2 FALK, supra note 28, at 651,675 . Wormuth, supra note 28 , at 781 , recognizes the Resolution as a "blank check," but argues principally that it is void as an impermissible delegation of legislative power. See id. at 781-99. The problem of delegation is discussed at pp. 885-892 infra.

91110 Cong. Rec. 18418 (1964). See also $i d$. at 18406, $18410,18419$.

Professor Velvel's treatment of the debate on the Tonkin Gulf Resolution, and other Congressional votes in support of the Vietnam policy, is extraordinarily selective. For 
many hundreds or thousands" of casualties is hardly a phrase to be applied to a limited reprisal for an attack on two naval vessels.

But Professor Velvel's argument for treating the Tonkin Gulf Resolution as a nullity is inadmissible for a more fundamental reason, even without invoking Justice Jackson's sardonic comment that some would look to the text of a statute only when its legislative history is ambiguous.

The Congress which passed the Tonkin Gulf Resolution and similar legislative declarations lived in the shadow of the long, bitter, and frustrating campaign of Korea. Of course neither the President nor any member of the Congress wanted to repeat that experience if it could possibly be avoided. Of course they hoped that a firm manifestation of American will would persuade the North Vietnamese government and those who supported it to accept the repeated offers of negotiation and

example, he refers to an exchange between Senator Brewster and Senator Fulbright in these terms:

At 112 [110] Congressional Record 18403 Senator Brewster said that he "would look with great dismay on the landing of large land armies on the continent of Asia." He therefore asked Senator Fulbright if the Resolution would approve "the landing of large American armies in Vietnam or China." Senator Fulbright replied, "There is nothing in the resolution, as I read it, that contemplates it. I agree with the Senator that that is the last thing we would want to do." Senator Fulbright, speaking for the Senate Foreign Relations Committee, continued by stating that everyone he had heard agreed that the United States must not become involved in an Asian land war and that the purpose of the Resolution was to deter the North Vietnamese from spreading the war. Senator Fulbright admitted that the language of the Resolution would not prevent the President from escalating the war, but he clearly indicated that this was not the congressional intent. The intent did not contemplate vast escalation, but deterrence of it.

Velvel, supra note 90, at 473-74, in 2 FALK, supra note 28 , at 651, 675-76.

What Senator Fulbright said, in his exchange with Senator Brewster about the use of the armed forces on the continent of Asia, is this:

There is nothing in the Resolution that, as I read it, contemplates it. I agree with the Senator that that is the last thing we would want to do. However, the language of the resolution would not prevent it. It would authorize whatever the Commander in Chief feels is necessary. It does not restrain the Executive from doing it. Whether or not that should ever be done is a matter of wisdom under the circumstances that exist at the particular time it is contemplated. . . .

110 CoNG. REC. 18403 (1964) (emphasis added).

When President Johnson made his decision to send troops to Vietnam on a large scale in the spring of 1965, he sought and obtained another vote from Congress, through an appropriation bill accompanied by a message which said:

This is not a routine appropriation. For each member of Congress who supports this request is also voting to persist in our effort to halt Communist aggression in South Vietnam. Each is saying that the Congress and the President stand united before the world in joint determination that the independence of South Vietnam shall be preserved and Communist attack will not succeed.

Message of May 4, 1965, in SENATE CoMmITTEE ON ForEIGN RELATIONS, BAcKground INFormation Reiating to Southeast Asia and Vietnam, 89th Cong., Ist Sess. 219 (Comm. Print rev. ed. 1965).

The Committee Reports and debates associated with this appropriation make it clear that the vote was indeed a reiteration and reaffirmation of the policy and of its implementation. Comparable debates, and votes, occurred in 1966 as well. These materials are magisterially reviewed in Moore \& Underwood, supra note 50, at 15553-67. 
compromise which the United States put forward, notably that contained in President Johnson's Baltimore speech of April 7, 1965. ${ }^{22}$ But these men knew too that of all human enterprises, recourse to military power is the least susceptible to easy prediction or control. It is always replete with nasty surprises, disappointments, and setbacks, campaigns that could not possibly have been anticipated when the initial decision to use force was undertaken. They knew too that solemn and public declarations of this order are addressed not only to the American people, but to those of the world at large, friendly and unfriendly governments alike, who are required to rely on what Congress does, not on the private fears and reservations of some of the men who voted for a text which said what it said.

Nor can the argument of deception be given any weight in evaluating the legal effect of legislation. Astute and worldly men who spoke and voted for SEATO, the Tonkin Gulf Resolution, and other legislative steps into the Vietnam War now claim that they were brainwashed, and that we should therefore treat public acts of the United States as if they never happened. Washington is a living society, not a series of closed enclaves labelled "legislative" and "executive." The atmosphere of that society consists of far more than formal messages and texts, testimony and votes. Congressmen and Senators live in a maze of information, rumor, speculation, and gossip, the product of continuous processes of consultation, leakage, and seepage between the executive and the legislative branches at all levels, as well as the table talk of journalists, ambassadors, and other regular and occasional members of the community-consultants, members of advisory committees, and so on. The key Congressmen and Senators responsible for the passage of the Tonkin Gulf and other Vietnam Resolutions knew what the executive branch knew when they voted. For some of these men to claim now that they were brainwashed is not only unseemly, but incredible.

As the basis for an argument that would justify the courts or anyone else in ignoring these Resolutions, the claim ranks with the historic efforts to treat the fourteenth amendment as a nullity because it was ratified by a number of state legislatures which met in the coercive presence of an army of occupation, and in some instances were elected by dubious and indeed fraudulent procedures. Many of these contentions are true, but a public act of the United States stands on its own

921 Public Papers of the Presidents: Lyndon B. Johnson 394, 396 (1966). 
foundations, officially and legally, and cannot be collaterally attacked on such grounds.

\section{B. Undue Delegation of Legislative Authority}

Professors Velvel, Wormuth, and Bickel advance another contention in their effort to exorcise the Tonkin Gulf Resolution and other legislation supporting the war in Vietnam. To them, the cycle of Presidential, Senatorial, and Congressional decisions with regard to Vietnam, regularly renewed over a period of more than sixteen years, is insufficient to satisfy what they regard as the unambiguous requirements of constitutional orthodoxy. Through a process of reasoning worthy of Justice Black in his most fundamentalist moments, they argue that, save for minor exceptions, hostilities can be authorized only by Congressional action at the time they begin, and then by delegations narrowly limited in scope. In their opinion, neither a treaty nor a congressional resolution can authorize a President to use force in advance of the event. Such provisions, they argue, unconstitutionally delegate legislative power to the President, because they are not suitably limited to the circumstances of the event which gave rise to the resolutionin the case of the Tonkin Gulf Resolution, the attack on American naval vessels in the Gulf of Tonkin.93

The Javits Bill does not accept this theory. Indeed, to Professors Velvel, Wormuth and Bickel, the Javits Bill is as unconstitutional as the Tonkin Gulf Resolution itself. ${ }^{84}$ For the Javits Bill concedes that an explicit and advance Congressional authorization of the President's use of force is constitutionally proper, provided it is voted after the passage of the Javits Bill and explicitly exempts the authorization from its restrictions or, if voted before the passage of the Javits Bill, is suffciently "specific." As a practical matter, the sponsors of the Javits Bill could hardly embrace the Velvel-Wormuth-Bickel theory of delegation. If congressional resolutions or other acts, like those for Formosa, United Nations participation, the Middle East, Berlin, and the expansion of Castro's power, were nullities whose operative provisions had to be repeated every time a President wanted to put them into action, it would be impossible for Congress and the President to cooperate at all

93 Velvel, supra note 90, at 478, in 2 FaLK, supra note 28, at 651, 680; Wormuth, supra note 28, at 780-99; 1971 Hearings, supra note 1 , at 549, 554-55, 560-63 (testimony of Alexander M. Bickel). "[T] authorized anything, beyond an immediate reaction, beyond its own factual context, it was an unconstitutionally broad delegation." Id. at 563.

04 See testimony cited in note 93 supra. 
in planning and formulating foreign policy in a way that would be credible.

Velvel, Wormuth, and Bickel discover the source of their rule in what they regard as the original intent of the men who gave Congress the power "to declare war," despite 182 years of opinion and practice to the contrary. The principle of full legislative control of the military power, they argue, precludes much Presidential discretion, and requires Congressional action only at the ritual moment, and then only in terms addressed to defined circumstances. Advance approval for the use of force they regard as a transfer to the President of a power Congress cannot yield even for a moment, even though it retains full authority to change the course of the nation thereafter by repealing, modifying, or reversing its policy, and the President's.

These scholars do not of course claim that Congressional support for the use of force by the President can be given only through a document labelled a "Declaration of War." Nor do they quite deny that the President has some inherent and independent power to use the force of the nation in aid of his conduct of foreign relations, as commanderin-chief of the armed forces, and as chief executive, charged with ensuring that the laws and treaties of the United States be faithfully executed. Without clarifying their views on these questions, however, and above all without considering the constitutional propriety of the Korean War, Wormuth and Bickel in particular conclude that the Tonkin Gulf Resolution, explicitly passed to reinforce and reiterate the policies of the SEATO Treaty, should be regarded as violating the principle they propose.

Actually, the Tonkin Gulf Resolution would appear to be beyond censure even under Bickel's extraordinary rule, since there had been some use of force by the United States in Vietnam, and Congress knew more was being considered at the time the Resolution was passed. Furthermore, the Tonkin Gulf Resolution would seem to contain suitably practical and defined standards to channel and confine the President's authority: it was addressed to what Congress and the President had found to be an "armed attack" by North Vietnam on South Vietnam within the meaning of the SEATO Treaty; and it could be terminated by Congress through a concurrent resolution, that is, without risk of veto. It is hard to conceive of a more precise or controlled "delegation" than one to help defeat a particular attack by one named state against another, pursuant to a policy already embodied in a Treaty.

More broadly, however, the Velvel-Wormuth-Bickel delegation 
argument falls before a series of Supreme Court decisions going back at least to Martin v. Mott, ${ }^{95}$ upholding standing delegations of discretion to the President in areas close to those of his independent constitutional responsibilities, and in areas of purely Congressional concern as well.

In advancing the argument that the Tonkin Gulf Resolution constitutes an unconstitutional delegation of Congress' power to declare war-which is assumed to include an equally unique power to authorize undeclared war-the commentators, especially Professor Bickel, place some reliance on Kent $v$. Dulles. ${ }^{96}$ That important case considered the legality of denying a passport to Rockwell Kent on the ground that he was a member of the Communist Party. The basic statute on the subject goes back to 1856, and provides that "the Secretary of State may grant and issue passports ... under such rules as the President shall designate and prescribe for and on behalf of the United States, and no other person shall grant, issue or verify such passports." In modern times the passport has become an important facility of international travel, and indeed a 1952 statute purports to make it unlawful for a citizen to depart from or enter the United States without a valid passport.

The Supreme Court upheld 'Kent's right to a passport, in an opinion which did not reach the question of constitutionality. Starting with the premise that the right to travel was an aspect of liberty protected by the Fifth Amendment, the court hesitated to infer from a pattern of longstanding administrative practice, which it found ambiguous at best, a Congressional purpose to authorize so drastic a curtailment of the liberty of the citizen. Interpreting the statute to avoid constitutional doubts, the court concluded that it should not construe Congressional silence to permit the Secretary to deny passports to individuals on the basis of their political opinions or associations. "If we were dealing with political questions entrusted to the Chief Executive by the Constitution," the Court said, "we would have a different case." the court wrote, was concerned only with the personal right of the citizen to travel:

If that 'liberty' is to be regulated, it must be pursuant to the law-making functions of the Congress. ... And if that power is delegated, the standards must be adequate to pass scrutiny by the accepted tests. ... Where activities or enjoyment, natural and often necessary to the well-being of an American citizen,

9525 U.S. (12 Wheat.) 19 (1827).

90357 U.S. 116 (1958). See 1971 Hearings, supra note 1 , at 555.

97357 U.S. 116, 129 (1958). 
such as travel, are involved, we will construe narrowly all delegated powers that curtail or dilute them. ... We hesitate to find in this broad generalized power an authority to trench so heavily on the rights of the citizen. ... We only conclude that $\S 1185$ and $\S 21$ la do not delegate to the Secretary the kind of authority exercised here. ${ }^{98}$

The limits of Kent $v$. Dulles were explored in Zemel v. Rusk, ${ }^{99}$ considering the same statute, in the context of the same argument that Congress had acquiesced through silence in a long-standing pattern of administrative practice in construing and applying the passport act. Zemel dealt with the Secretary of State's refusal to validate a citizen's passport for travel to Cuba during 1962, a tense period in Cuban-American relations culminating in the Guban Missile Grisis. In 1961 the Department of State had issued regulations requiring passports for travel to Cuba, and the specific endorsement of such passports by the Department before a citizen could travel to Cuba. Mr. Zemel said the purpose of his trip was "to satisfy my curiosity about the state of affairs in Cuba and to make me a better informed citizen."100

Reviewing the history of periodic restraints of travel to areas of war, pestilence, famine, or disorder since 1915 - that is, both before and since the reenactment of the statute of 1856 in 1926-the Court upheld the Department's position. The issue of statutory construction in Kent, the court said, was "whether a citizen could be denied a passport because of his beliefs or associations." 101 In Zemel, however, the issue before the court, as a question of both statutory interpretation and constitutional law, was whether the Secretary could refuse to validate a citizen's passport for travel to Cuba "because of foreign policy considerations affecting all citizens."102

The Court concluded that the history of the problem justified the inference that the statute did delegate to the President an unreviewable discretion to restrict travel to areas where for reasons of foreigu policy, ${ }^{103}$ and indeed for weighty considerations of national security, ${ }^{104}$ unlimited travel by citizens could "directly and materially interfere with the safety and welfare of the area or the Nation as a whole."105 
In Zemel, unlike Kent, the Court was therefore required to pass on the constitutional validity of such a delegation of legislative authority. It said:

Finally, appellant challenges the 1926 Act on the ground that it does not contain sufficiently definite standards for the formulation of travel controls by the Executive. It is important to bear in mind, in appraising this argument, that because of the changeable and explosive nature of contemporary international relations, and the fact that the Executive is immediately privy to information which cannot be swiftly presented to, evaluated by, and acted upon by the legislature, Congressin giving the Executive authority over matters of foreign affairs-must of necessity paint with a brush broader than that it customarily wields in domestic areas.

"Practically every volume of the United States Statutes contains one or more acts or joint resolutions of Congress authorizing action by the President in respect of subjects affecting foreign relations, which either leave the exercise of the power to his unrestricted judgment, or provide a standard far more general than that which has always been considered requisite with regard to domestic affairs." United States v. Curtiss-Wright Corp., 299 U.S. 304, 324.

This does not mean that simply because a statute deals with foreign relations, it can grant the Executive totally unrestricted freedom of choice. However, the 1926 Act contains no such grant. We have held, Kent v. Dulles, supra, and reaffirm today, that the 1926 Act must take its content from history: it authorizes only those passport refusals and restrictions "which it could fairly be argued were adopted by Congress in light of prior administrative practice." Kent v. Dulles, supra, at 128. So limited, the Act does not constitute an invalid delegation. ${ }^{106}$

Thus, Kent and Zemel together would seem to confirm, not to challenge, the constitutional validity of the Tonkin Gulf Resolution.

The Courts have upheld other broad delegations of discretion to the President, including many in areas which are purely legislative in character and have no roots in one or another of the inherent powers of the Presidency: in the field of tariffs and of responsibility for banking, to take only two examples. ${ }^{107}$ The distinction in Zemel between delega-

$108 \mathrm{Id}$. at 17-18.

10719 U.S.C. $\$ \S 181,1336-38$ (1970) (tariff statutes delegating to the President power over rates and duties); 12 U.S.C. $\$ \S 95-95 \mathrm{a}$ (1970) (President's emergency powers over banks). 
tions in the field of domestic and of foreign affairs is frequently made, and certainly the conduct of foreign affairs requires the flexibility of broad discretion. Still, it is hard to imagine a "delegation" more complete than that of Martin $v$. Mott, for example, involving the President's power to call out the militia whenever he deems it desirable to do so. Generally speaking, the reasonableness of a delegation should be considered in relation to the nature of the problem Congress was trying to resolve, and its freedom within broad limits to select means which might conceivably contribute to the end it sought to achieve. ${ }^{108}$

No standard even reasonably close to the precedents and their reasoning provides support for the argument that the Tonkin Gulf Resolution can be treated as a nullity because it constitutes an unconstitutional delegation of legislative power. This cannot be the basis for Senator Fulbright's position that the war in Vietnam is "unconstitutional,"109 since the Javits Bill, which he supports, contemplates the possibility that Congress and the President might well decide to use advance statutory authorizations for the use of armed force by the President. ${ }^{110}$

The argument of undue delegation fails for a deeper reason. It is at war with the "nature of things," those stubborn exigencies of the external world that Montesquieu rightly saw as the true source of law, the nature of things in the late eighteenth century and the nature of things now. The necessities of circumstance in dealing with the hurly-burly of the real world have produced a quite different pattern of practice since 1789, not less democratic than the model in the minds of Professors Bickel, Wormuth, and Velvel, but far more flexible, resourceful, and effective. To treat Resolutions like the Tonkin Gulf Resolutions as nullities would make it nearly impossible to associate Congress with the President in the articulation of an effective deterrent diplomacy. Such a rule would nake foreigu affairs even more exclusively the province of the President than is the case today.

In Marshall's classic words, echoing those of Hamilton in No. 23

See also Comment, Federal Taxation and Economic Stability, 57 YaLE L.J. 1229, 1248-55 (1948).

108 E. Corwin, The Prestdent: Office and Powers 369-73 (1940) (a compilation of the discretionary powers of the President in 1940). See also E. CoRWIN, supra note 30, at 11930; K. Davis, Administrative Law Treatise \$ 2.00 (1970 Supp.); Jaffe, An Essay on Delegation of Legislative Power, 47 ColuM. L. REv. 359, 561 (1947).

109 WAR Powers, supra note 1, at 27; Fulbright, Congress, the President and the War Power, 25 ARk. L. REv. 71, 72 (1971). See also testimony of Alexander Bickel in 1971 Hearings, supra note 1 , at 566-77, 579 .

110 S. 2956, $92 d$ Cong., $2 d$ Sess. $\$ 3(4)$ (1972). 
of The Federalist, the first rule in interpreting "those great powers on which the welfare of a nation essentially depends" is that

[i]t must have been the intention of those who gave these powers, to insure, as far as human prudence could insure, their beneficial execution. This could not be done by confiding the choice of means to such narrow limits as not to leave it in the power of Congress to adopt any which might be appropriate, and which were conducive to the end. This provision is made in a constitution intended to endure for ages to come, and, consequently, to be adapted to the various crises of human affairs. To have prescribed the means by which government should, in all future time, execute its powers, would have been to change, entirely, the character of the instrument, and give it the properties of a legal code. It would have been an unwise attempt to provide, by immutable rules, for exigencies which, if foreseen at all, must have been seen dimly, and which can best be provided for as they occur. To have declared that the best means shall not be used, but those alone without which the power given would be nugatory, would have been to deprive the legislature of the capacity to avail itself of experience, to exercise its reason, and to accommodate its legislation to circumstances. ... .111

Marshall had noted previously that

[t] he power being given, it is the interest of the nation to facilitate its execution. It can never be their interest, and cannot be presumed to have been their intention, to clog and embarrass its execution by withholding the most appropriate means. ${ }^{112}$

What Marshall wrote about the power of Congress to charter a bank in McCulloch v. Maryland applies even more emphatically to the respective roles of the President and Congress in exercising the great powers of the nation abroad, powers whose constitutional contours derive as much from international law and international life as from the deliberately few words of the document of 1787 .

The American nation which entered the family of nations in 1776 was endowed in its external relations with all the attributes of sovereignty. The written constitution which went into effect in 1789 must be read, Justice Frankfurter has said, to recognize in the national gov-

111 McCulloch v. Maryland, 17 U.S. (4 Wheat.) 316, 415-16 (1819.)

$112 I d$. at 408. 
ernment "the powers indispensable to its functioning effectively in the company of sovereign nations." 113

The delegation theory of Professors Velvel, Wormuth, and Bickel would deny the President and the Congress the most ordimary and elementary tools for protecting the nation in a time of international turbulence. Under their rule, we should be the only nation on earth incapable of making a credible military treaty. Their rule would make it impossible firmly to delineate American interests in advance, and thus to deter and contain processes of expansion which Congress and the President deem threatening to national security. It would emasculate both Congress and the Presidency, and deprive even treaties like NATO of their weight and credibility.

The Constitution, Justice Goldberg once said, is not "a suicide pact."I14 The war power, the Supreme Court has remarked, is the power to wage war successfully. So too, the power of the President and of the Congress over foreign relations is the power to wage peace successfully. There is nothing in the history of the war power and the foreign relations power, since President Washington's first term, to suggest that the United States may not seek to avert the danger of war by giving potential enemies of the nation a credible and effective warning in advance. McCulloch v. Maryland teaches that those who oppose the presumptive constitutional validity of the means Congress and the President together select as appropriate to protect the security of the nation face a nearly insuperable burden of proof..$^{115}$

\section{The Political Question Doctrine}

It is sometimes claimed that the "political question" doctrine makes it impossible to reach final decisions-that is, "final" decisions by courts-on the constitutionality of procedures like those used by Presidents and Congress in Korea and Vietnam. This contention misconceives the political question doctrine. It is not, as some contend, a flexible and amorphous idea used by the Courts to avoid questions they do not wish to decide, although judges sometimes use it for this purpose. As Marshall made clear in Marbury v. Madison, ${ }^{116}$ the doctrine is something quite different: that courts cannot and should not pass on the

113 Perez v. Brownell, 356 U.S. 44, 57 (1958).

114 Aptheker v. Secretary of State, 378 U.S. 500, 509 (1964).

11617 U.S. (4 Wheat.) 316, 409-11 (1918).

1165 U.S. (1 Cranch) 137 (1803). 
propriety of decisions entrusted by the Constitution or the laws to the discretion of another branch of government. ${ }^{117}$

In Marbury's case, no court could have questioned the propriety of the President's decision to nominate Marbury rather than John Doe or Richard Roe; the Senate's vote in its absolute discretion to advise his appointment, and consent to it; or the President's final decision, having received a favorable vote from the Senate, to sign Marbury's commission, and have it sealed. The question became justiciable, the Court said, only because the political discretion of the President and the Senate was exhausted when the seal was affixed. At that moment, and not before, Marbury acquired a vested legal right, a property interest, in the office.

The question whether Marbury's right to the judgeship should be protected in court, the Court said, "far from being an intrusion into the secrets of the cabinet, ... respects a paper, which, according to law, is upon record, and to a copy of which the law gives a right, on the payment of ten cents."118

Like nearly all the intervening cases, Powell v. McCormack ${ }^{119}$ rests upon the same simple principle. The Court did not attempt to control the political decision of Congress to exclude Adam Clayton Powell, duly elected to membership in Congress. It carefully ruled, however, that while under the Constitution each House was indeed "the Judge of the Elections, Returns and Qualifications of its own members," the discretion of Congress over the admission of members could rest only on the grounds specified in the constitution-age, citizenship, residence, and election. Since it was conceded in this case that Powell met these

117 The intimate political relation, subsisting between the president of the United States and the heads of departments, necessarily renders any legal investigation of the acts of one of those high officers peculiarly irksome, as well as dehicate; and excites some hesitation with respect to the propriety of entering into such investigation. Impressions are often received without much reflection or examination, and it is not wonderful that in such a case as this, the assertion, by an individual, of his legal claims in a court of justice; to which claims it is the duty of that court to attend; should at first view be considered by some, as an attempt to intrude into the cabinet, and to intermeddle with the prerogatives of the executive.

It is scarcely necessary for the court to disclaim all pretensions to such a jurisdiction. An extravagance, so absurd and excessive, could not have been entertained for a moment. The province of the court is, solely, to decide on the rights of individuals, not to enquire how the executive, or executive officers, perform duties in which they have a discretion. Questions, in their nature political, or which are, by the constitution and the laws, submitted to the executive, can never be made in this court.

Id. at $169-70$.

118 Id. at 170 .

119395 U.S. 486 (1969). 
constitutional qualifications, which were unalterable by the legislature, it followed that the vote excluding him was invalid. ${ }^{120}$ The Court took exactly the same position in Roudebush v. Hartke: "Which candidate is entitled to be seated in the Senate is, to be sure, a nonjusticiable political question."121

By now many lower courts, faced with the complaint of young men about to be drafted into the armed forces, have passed upon the constitutionality of the war in Vietnam. Such plaintiffs surely have standing to raise the question, in the sense of a direct personal interest in the outcome of the litigation; the possibility that they may be killed or maimed in the course of military operations represents the most direct and most personal of all interests. I can imagine no civil right more profound, and more to be respected, than the right of a conscript to be assured that the war he is required to fight has been constitutionally authorized. All the courts which have passed upon the question have given these plaintiffs the answer Justice Story gave to the militiamen in Martin v. Mott: that whether the United States acts or does not act under a treaty; whether it decides to help or not to help a friendly government in measures of self-defense against a rebellion aided or instigated and organized from abroad; whether the President and Congress "declare" war, or choose the course of limited war-all are matters peculiarly within the discretion entrusted to the President, or to Congress, or to both, under our constitution and laws and, therefore "political" questions within the meaning of Marbury $v$. Madison. ${ }^{122}$ When Courts decide that the way in which the political arms of the government exercise such discretion is a "political question," they are not abstaining from a decision on its legality; on the contrary, they are deciding that the choices made were within the zone of discretion entrusted to the political branches of the government, and are therefore legal.

I should be the last to urge, as some have done, that the courts should refrain from decisions of this kind on the ground that it may be

$120 \mathrm{Id}$. at $518-22,548-49$.

12192 S. Ct. 804, 807 (1972). See Dionisopoulos, A Commentary on the Constitutional Issues in Powell and Related Cases, 17 J. PUB. L. 103 (1968); Henkin, Viet-Nam in the Courts of the United States: "Political Questions," 63 AM. J. INT'L L. 284 (1969); Scharpf, Judicial Review and the Political Question: A Functional Analysis, 75 YAlE L.J. 517 (1966); Schwartz \& McCormack, The Justiciability of Legal Objections to the American Military Effort in Vietnam, 46 TEXAS L. REv. 1033 (1968).

122 See, e.g., Orlando v. Laird, 317 F. Supp. 1013 (E.D.N.Y. 1970), aff'd, 443 F.2d 1039 (2d Cir.), cert. denied, 404 U.S. 869 (1971); United States v. Sisson, 294 F. Supp. 511, 515, 520 (D. Mass. 1968), 297 F. Supp. 902 (D. Mass. 1969), appeal dismissed for lack of jurisdiction, 399 U.S. 267 (1970). 
impractical and undesirable to have the courts pass on such difficult and sensitive problems. ${ }^{123}$ On the contrary, I believe that many exercises of the military power do produce justiciable controversies, and that in such cases the courts should review the exercise of the war power by political authority to make sure it is kept within constitutional limits. I believe our national debate about Vietnam might well have been less confused and less poisonous if the Supreme Court, in a great opinion, had said what the lower courts have all said-and what I think any judge under the pressure of responsibility would necessarily conclude-that there is no constitutional basis for challenging the legality of the war in Vietnam. Men can reasonably debate whether the United States should have made the commitment of the SEATO Treaty, or honored its commitment when the Treaty was breached. They can argue about the strategy and tactics of the combat and diplomacy of the war in IndoChina. Equally, with Senator Cooper they can question whether a vote of Congress was necessary, in addition to a Treaty, to authorize the President to use the national force on a large scale in Vietnam. But when President and Congress pool all the war powers they possess, jointly and separately, what is there left to debate? It is difficult, at least for me, to discover any plausible basis for contending that the Vietnam War is unconstitutional, or even constitutionally doubtful.

\section{D. "Necessary and Proper"}

In the tense and cautious diplomacy of our present relations with the Soviet Union, as they have developed over the last twenty-five years, the authority of the President to set clear and silent limits in advance is perhaps the most important of all the powers in our constitutional armory to prevent confrontations that could carry nuclear implications. No shots have been fired between the armed forces of the United States and those of the Soviet Union; and the inhibition against firing the first shot has been an immensely powerful factor of restraint in the conduct of the cold war. The basic rule of cold war diplomacy, thus far, has been that the Soviet Union does not use force to challenge our presence, or what we clearly and privately inform them are our state interests, and

123 See Rostow, The Japanese American Cases-A Disaster, 54 YALE L.J. 489 (1945), reprinted in E. Rostow, The Sovereign PRERogative 193 (1962); H. WechSLER, PrINCIPLes, Poltrics, and Fundamental Law $11-13$ (1961). Cf. A. Bickel, The Least Dangerous Branch $69-70$ (1962); T. Taylor, Nuremberg and VietNam: AN American Tragedy 109-13, 116-21 (1970). The limits of presidential power in war have never been better analyzed than by Justice Curtis in his pamphlet Executive Power (1862), reprinted in II B. CuRTIs, A Memoir of Benjamin Robbins CurTis, L.L.D. 306 (1879). 
that we likewise do not use force to oppose hers. We did not intervene in East Germany, Hungary, or Czechoslovakia. They did not use their own force to oppose our actions in Berlin, in Yugoslavia, in Greece, in Korea, and in Vietnam. In resisting the Berlin Blockade, President Truman carefully chose the air lift, a method of action that would have required the Soviets to fire the first shot. President Kennedy sought to accomplish the same end in his handling of the Cuban Missile Crisis, cautiously choosing a limited naval blockade rather than air strike or invasion, the latter strongly urged upon him by Senator Fulbright and others. ${ }^{124}$

The nature of the problem requires promptness of action, great flexibility in the choice of means, and freedom to shift, from hour to hour, in response to the exigencies of the diplomatic situation. It puts a decisive premium on establishing a deterrent presence, or a credible deterrent threat, before irrevocable steps have been taken, or decisions made.

The Javits Bill purports to abolish this power-essential to diplomacy, and to the process of avoiding war. It is a power which nearly every President has used, at least since 1794, when President Washington sent troops to drive Indians-perhaps supported by the Britishfrom Western territories in dispute. And it is the diplomatic power the President needs most under the circumstances of modern life-the power to make a credible threat to use force in order to prevent a confrontation which might escalate.

I believe that an attempt by Congress to deprive the President of power so crucial to his duties as organ of the nation in the conduct of foreign relations is unconstitutional. It is as unconstitutional as a Presidential assumption of power deemed legislative, or as Congressional invasions of the President's much mooted power to remove subordinate officials of the Executive branch, or his pardoning power, or of the authority of the courts under Article III. ${ }^{125}$

The Senate Foreign Relations Committee claims to have discovered new potentialities in the necessary and proper clause authorizing Congress to control the way in which "any Department or officer thereof"

$124 \mathrm{R}$. KENNEDY, supra note 12 , at $32,119$.

$125 \mathrm{See}$, e.g., Wiener v. United States, 357 U.S. 349 (1958); Reid v. Covert, 354 U.S. I (1957); Myers v. United States, 272 U.S. 52 (1926); Muskrat v. United States, 219 U.S. 346 (1911); United States v. Klein, 80 U.S. (13 Wall.) 128, 147-48 (1871); Ex Parte Yerger, 75 U.S. (8 Wall.) 85 (1869); Ex Parte Garland, 71 U.S. (4 Wall.) 333, 380 (1867); Marbury v. Madison, 5 U.S. (1 Granch) 137 (1803); E. Corwin, The PresioEnT's REMoval Power UNDER THE CONSTITUTION (1927). This argument was the heart of the impeachment proceedings against President Andrew Johnson. See B. CuRTIs, supra note 123, at 343. 
exercises its functions. But the necessary and proper clause, impressive as it is, cannot be the source of a bootstrap doctrine, empowering Congress to abolish the principle of the separation of powers. Every piece of legislation has as its tacit predicate a Congressional finding that the statute or resolution is, in the view of Congress, "necessary and proper for carrying into Execution" one or another of the powers allocated to it in Article I, Section 8. Congress has been talking the prose (or poetry) of the necessary and proper clause since 1789 .

\section{Conclusion}

The Javits Bill and similar proposals represent the passionate conviction that the campaigns in Korea and Vietnam were a mistake. Many proponents of the Bill also contend that Korea and Vietnam were "Presidential" wars, and could have been avoided if only Congress had not been stripped of its rightful powers by the usurpations of overweening modern Presidents. We are therefore in the midst of a constitutional crisis, they tell us, a crisis which can be cured, and equilibrium in the constitutional order restored, only by the passage of a statute like the Javits Bill. Men like Senator Cooper and Senator Stennis, of course, do not accept this step in the argnment. They know that Korea and Vietnam did not come about because the Presidency had arrogated Congress' powers over foreign policy; Congress fully supported those efforts when they were undertaken. But Senators Cooper and Stennis support the Javits Bill for another reason: they are trying to take advantage of the present state of opinion about Korea and Vietnam to establish certain Congressional prerogatives they have long urged in the perpetual conflict between Congress and the Presidency over their respective roles in making foreign policy. Their effort is addressed to the constitutional practice of Korea, not Vietnam. It represents Bricker's thesis that treaties are not self-executing, but require Congressional action before they become law.

The nation is in the midst of an important foreign policy crisis. It is not a constitutional crisis requiring a redefinition of the relationship between the President and the Congress, but an intellectual and moral crisis caused by a growing tension between what we do and what we think. The ideas that for twenty-five years have shaped American foreign policy, and the foreign policy of our Allies-the visions which dominated the minds of the delegates who met at San Francisco in 1945 to write the Charter of the United Nations-have suddenly lost their power to command. When the delegates met at San Francisco in 1945, 
they saw Haile Selassie standing sadly before them, as he had stood in the Palace of the League of Nations ten years before, asking in vain for help against Mussolini's aggression. With equal shame they remembered China, which had also met silence when it besought the League to stop Japan. If the world had acted promptly, and in concert, would Japan have conquered Manchuria, and gone on to wage general war against China, and then against others? Would Italy have attacked harmless Ethiopia? Would Germany and Italy have made war against Spain, by sending arms and men to support Franco's revolution? Would the Rhineland have been occupied, Austria and Czechoslovakia invaded? In short, could the drive towards war have been stopped earlier, before its momentum became irresistible?

To the men of 1945, the answer to these questions was self-evident. World War II could have been prevented, they believed, if Britain, France, and the United States had acted against aggression, firmly, boldly, and above all in good time.

Today there is an outcry against these ideas. Something is wrong with the notion of small wars to prevent big ones, men say, if it produces consequences as ghastly as the campaigns in Korea and Vietnam. There must be a "new" foreign policy that could liberate us from the burdens we have had to bear since 1945 .

This demand is the most conspicuous theme of a bellicose literature about how to achieve peace. It is conventional to describe that literature as a "Great Debate." Like many features of the conventional wisdom, the phrase is misleading. There is disagreement to spare in these books and articles, but little or no debate. Few of the protagonists read what their opponents write, or listen to what they say. Generally speaking, arguments are answered by epithets. The devotees of geopolitics, brooding about nuclear deterrence, dismiss their critics as amateurs, demagogues, journalists, dupes, or worse. Their critics return the compliment. Why should they waste time considering the ideas of fascists, war criminals, revisionists (or other lackeys of monopoly capitalism), or burnt-out cases whose minds were paralyzed in cold war postures twenty years ago?

In contemplating our national priorities, I can think of nothing we need more urgently than a genuine debate about what foreign policy is for. Until we come much closer to agreement on this central question, we shall have little opportunity to deal with the others.

Since 1945, there has been acute dissonance in the nation between what we thought and what we did in the name of foreign policy. While 
neither the United States nor any other nation has ever dared contemplate the full-throated enforcement of the United Nations Charter -in Eastern Europe, for example-American policy has nonetheless been strongly influenced by the experience of the thirties, and by the ideas of the Charter. President Truman regarded the Korean War as atonement for the League's failure in Ethiopia. His point was underscored by the presence of Ethiopian troops in Korea. And the memory of Munich, and of President Wilson, is a living part of American consciousness.

Truman's view has not, of course, been universally accepted. The United States has offered many explanations for its foreign policy since the Truman Doctrine was announced in 1947: as the "containment" of "Communism," or of the Soviet Union, China, and Cuba; as the protection of "free nations" or of "the free world"; as the manifest destiny of a Great Power; or as the application of the oldest and most nearly instinctive policy in all politics-that of the balance of power.

Public opinion has not yet crystallized around any one of these competing principles as the proper compass for our foreign policy. Since 1945, the American government under five Presidents has felt compelled to act in a certain pattern, from Iran, Greece, and Turkey, to Berlin, Korea, the Middle East and Vietnam. But there is no harmony between this pattern of action, and widespread, and now perhaps prevailing views as to what American and Allied foreign policy ought to be.

The tension between public opinion and the behavior of government is much too great for safety. That tension has already destroyed the careers of two Presidents, Truman and Johnson; divided the nation; split the Democratic Party; and perhaps weakened the Presidency as well. It could have even more serious consequences, for it has given rise to uncertainty all over the world as to what the United States will do to protect its own security, and the security of nations it has undertaken to defend. Uncertainty of this order invites miscalculation, the kind of miscalculation which had led to so many catastrophes already during this brutal and tragic century. It is hardly hyperbole to conclude that the nation must reexamine its foreign policy before its foreign policy destroys the nation.

The real crisis of our foreign policy can be resolved only through a disciplined and scrupulous examination of what the nation must do, given the condition of world politics, to preserve the possibility of surviving as a democracy at home. That process will be difficult at best. 
The relevant Congressional Committees, and Congress as a whole, should be leading the nation in a courteous and sustained debate, through which we could hope to achieve a new consensus about foreign policy, as vital, and creative, as that which sustained the line of policy which started with the Truman Doctrine, the Marshall Plan, NATO and its progeny, and the Point Four Program.

Instead, the Senate Foreign Relations Committee has chosen to escape from the demanding but manageable task of reality by retreating into the insoluble and dangerous realin of constitutional myth. No one could possibly write the statute the Javits Bill purports to be-a codification of what the Founding Fathers prudently left uncodified, the respective powers of Congress and the President in relation to the use of the national force. As George Ball pointed out in his persuasive testimony opposing the Javits Bill, the Bill

represents an attempt to do what the Founding Fathers felt they were not wise enough to do: to give precision and automatic operation to the kind of legislative-executive collaboration which they deemed essential to prevent the unrestricted use of American forces by the Executive acting in the pattern of monarch, while at the same time assuring him sufficient flexibility to defend the country against any threats that might suddenly appear. ${ }^{126}$

In this time of trouble, almost as threatening to the nation as the Great European Wars of 1789-1815, we should not be diverted from the compelling task of rethinking foreign policy into a ritual purge of evil spirits, and an emasculation of the Presidency we have never needed more. The Javits Bill would turn the clock back to the Articles of Confederation, and destroy the Presidency which it was one of the chief aims of the men of Annapolis and Philadelphia to create.

1261971 Hearings, supra note 1 , at 621. 